\title{
A kontraszelekció hatása a tőzsdei specialisták árjegyzési stratégiájára*
}

\author{
Muratov-Szabó Kira - Váradi Kata
}

Tanulmányunk a tőzsdei kereskedésben jelentős szerepet játszó specialisták árjegyzésének modellezése olyan modellkeretben, amelyben a tranzakciókban részt vevö felek lehetnek informáltak és nem informáltak, vagyis likviditáskereskedök. Ezen kontraszelekciós modellkeretben Monte Carlo-szimuláció segítségével kerestük a következő kutatási kérdéseinkre a választ: a kontraszelekció miképpen hat a specialisták árjegyzésére; a bizonytalanság milyen hatással van az árfolyamok és a loghozamok alakulására; a kereskedési volumenekből a specialisták milyen pontossággal tudják meghatározni az informáltak és a likviditáskereskedók arányát. A modellünkkel alá tudtuk támasztani, hogy amint csökkent a bizonytalanság a modellezett piacon, úgy nött a tranzakciók száma, a vagyon és a részvényállomány, miközben csökkent az árfolyamok ingadozása, a loghozamok szórása és a loghozamok eloszlása egyre jobban közelítette a normális eloszlást, mely a piac hatékonyságának javulását mutatta.

Journal of Economic Literature (JEL) kódok: G12, G14, G17

Kulcsszavak: specialista, árjegyzés, kontraszelekció

\section{Bevezetés}

Tanulmányunkban a tőzsdei piacokon tevékenykedő specialisták árjegyzési stratégiáját vizsgáljuk. Specialista alatt olyan piacvezető személyt értünk a tőzsdei kereskedés során, akinek kizárólagos joga van vételi és eladási árat jegyezni egy adott termékben. A tanulmány alapját egyrészt Kornis (2017) munkája adta, aki az árjegyzői piacokon a specialista viselkedését, feltételezett stratégiáit vizsgálta, melyet mi a jegyzett volumen figyelembevételével egészítettünk ki. Másrészt Caglio és Kavajecz (2006) cikkére is épül a tanulmányunk, akik azt mutatták meg, hogy a specialista a jegyzett volument stratégiailag tudja használni a kontraszelekció kockázatának kezelésére. A kontraszelekció fogalma tanulmányunkban olyan értelemben jelenik meg, hogy a megbízást adó piaci szereplők egy része informált a termék várható

\footnotetext{
* A jelen kiadványban megjelenő írások a szerzők nézeteit tartalmazzák, ami nem feltétlenül egyezik a Magyar Nemzeti Bank hivatalos álláspontjával.

Muratov-Szabó Kira a Budapesti Corvinus Egyetem hallgatója. A tanulmány a 2017/2018-as tanévben leadott szakdolgozata alapján készült. Email: muratov.kira@gmail.com

Váradi Kata a Budapesti Corvinus Egyetem docense.Email: kata.varadi@uni-corvinus.hu
}

A magyar nyelvű kézirat első változata 2018. szeptember 24-én érkezett szerkesztőségünkbe.

DOI: http://doi.org/10.25201/HSZ.18.1.91127 
árfolyam-elmozdulásával kapcsolatban, másik része pedig nem informált, vagyis likviditáskereskedő. A specialista azonban nem tudja az árfolyamjegyzés során, hogy az, aki a megbízást adja, informált-e vagy sem, így nem tudja, hogy pontosan milyen árat lenne érdemes jegyeznie. Összességében tanulmányunk az említett két kutatást köti össze, a következő kutatási kérdésekre keresve a választ a felépített új modellben:

- Milyen hatással van a kontraszelekció a specialista árjegyzésére?

- Hogyan alakulnak az árfolyamok és a loghozamok a bizonytalanság különböző szintjei mellett?

- Milyen pontossággal tudja a specialista az informált kereskedők arányáról való véleményét alakítani a tranzakciók volumene alapján?

A részben Caglio és Kavajecz (2006), részben pedig Kornis (2017) munkájára épített modell rengeteg új feltételezést és új módszert tartalmaz. Az előbbi elsősorban az elméleti hátteret biztosította, az utóbbi pedig a gyakorlati megvalósítás terén adott ötleteket. A modell szimulálásához egy programot ${ }^{1}$ készítettünk Excelben, Visual Basic for Applications programozási nyelven.

Tanulmányunk a bevezetést követő második fejezetben összefoglalja a releváns nemzetközi szakirodalmat. A harmadik fejezet ismerteti Caglio és Kavajecz (2006) modelljét saját kiegészítéseinkkel, módszereinkkel bővítve, vizsgálva, hogy hogyan lehet bevonni a modellbe a kontraszelekció problémáját, kik azok az informált kereskedők, és kik a likviditáskereskedők, hogyan tudja őket a specialista azonosítani, és hogyan tudja maximalizálni a profitját. A negyedik fejezetben a szimuláció menete kerül röviden felvázolásra, előkészítve az ötödik fejezetet, mely a gyakorlati munka gyümölcseként a szimuláció során kapott eredmények statisztikai elemzéséről, az ábrák bemutatásáról, a következtetések levonásáról szól. A tanulmányt összefoglalás zárja, melyben összegezzük a bevezetőben feltett kérdésekre adott válaszokat.

\section{Irodalmi áttekintés}

A pénzügyi piacokon folytatott kutatások jelentős része végső soron - más-más irányból megközelítve - mindig arra a kérdésre keresi a választ, hogy miképpen lehet a piaci árakat előre jelezni, ami alapján nyereséges kereskedési stratégia építhető fel. Ezen a területen az elmúlt évtizedekben teret nyert a piaci mikrostruktúra irodalma, mely nem a tényleges áralakulásokból próbál következtetést levonni a várható árfolyamalakulásra vonatkozóan, hanem azt nézi meg, hogy az egyes piacok müködése hogyan hat az áralakulásra. Vizsgálják, hogy kik a piaci szereplők, milyen az informáltságuk, milyen a termékek jellege (pl. alaptermék vagy származtatott

\footnotetext{
${ }^{1}$ A program főbb elemeinek (szubrutinok és függvények) kódjai megtalálhatók a tanulmány függelékében.
} 
termék), tehát a piaci mikrostruktúra elemei alapján próbálnak következtetni a piaci hatékonyságra, illetve az árfolyam-alakulásra (O’Hara 1995).

A piaci mikrostruktúra egyik központi fogalma a piaci likviditás. Ez alatt azt értjük, hogy egy adott terméket milyen gyorsan lehet minél kisebb árhatással eladni vagy megvenni egy adott volumenben. Ezt általában mind a gyakorlati szakemberek, mind a tudományos kutatások a bid-ask spreaddel közelítik meg, ami a likviditás tranzakciós költségének mérőszáma, és a legjobb vételi és eladási ár közötti különbséget jelenti. Foucault et al. (2013) alapján a piaci mikrostruktúra egyik alapvető gondolata, hogy a bid-ask spread 1) kontraszelekciós (adverse selection), 2) készletezési (inventory control) és 3) ajánlat-feldolgozási (order-processing) költségekből épül fel (1. ábra), hiszen ezen költségekkel néz szembe a specialista a kereskedés lebonyolításakor, és az árak jegyzése során ezeket a költségeket hárítja át a piaci szereplőkre.

\section{1. ábra}

\section{A tranzakciós költség komponensei}

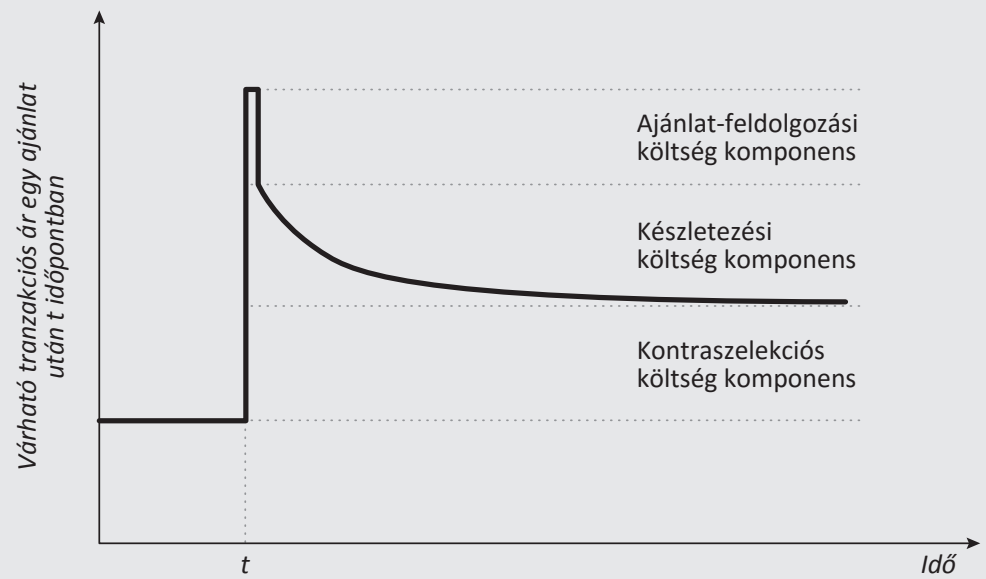

Forrás: Foucault et al. (2013), 121.o.

1. Kontraszelekciós költség: Mivel a jól informált kereskedők akkor vásárolnak, ha a jegyzett ár túl alacsony, és akkor adnak el, ha a jegyzett ár túl magas az információk szerint, ezért a specialista kontraszelekciós költségeknek van kitéve.

2. Készletezési költség: A folytonos piacokon a likviditási kereskedőktől érkező vásárlási és eladási ajánlatok nem egyidejüleg érkeznek, aminek következtében az ajánlatok között ideiglenes egyenlőtlenség alakul ki. A specialista feladata, hogy saját készlete terhére egyensúlyt teremtsen a kereslet és a kínálat között, miközben idővel a nettó pozíciója zéró. Ez a szerep azonban a specialistát készletezési kockázatnak teszi ki, hiszen a készletének értéke megváltozhat, például az 
eszközt érintő új információk, hírek miatt. Ennek okán a specialista készletezési költséget követel meg.

3. Ajánlatfeldolgozási költség: A kereskedési díjért, elszámolási és kiegyenlítési díjért, papírmunkáért, telefonálási időért és hasonlókért a specialista úgynevezett ajánlatfeldolgozási költséget számol fel.

Összességében tehát ezek a költségek végső soron a többi piaci szereplőt terhelik tranzakciós költségek formájában, ami maga a bid-ask spread (Foucault et al. 2013).

A tranzakciós költségek problémáját először Demsetz (1968) formalizálta. Úgy kezelte a bid-ask spreadet, mint az azonnali kereskedésre való lehetőség költségét. Bagehot (1971) megállapította, hogy a specialista (legalább) kétféle kereskedővel találhatja szemben magát: informált, illetve likviditási kereskedőkkel. Az informált kereskedők olyan nem publikus információkkal rendelkeznek, melyek segítségével pontosabban tudják megbecsülni az értékpapír jövőbeni árfolyamát, mint a likviditási kereskedők és maga a specialista. Mivel ezeknek a különleges információt birtokló kereskedőknek van lehetőségük arra, hogy ne kössenek üzletet a specialistával, a specialista sosem fog tudni nyerni velük szemben, legfeljebb veszíthet. Ezzel szemben a likviditási kereskedőkkel folytatott tranzakciókban nyerhet, mivel ezek a piaci szereplők hajlandók egy „díjat” fizetni az azonnali kereskedelem eléréséhez.

Ezt a két gondolatot fogta össze Copeland és Galai (1983), akik tanulmányukban a bid-ask spreadet „tradeoff”-ként modellezték, amely a specialistát az informált kereskedőktől várható veszteségekért a likviditási kereskedőktől várható nyereségekkel kárpótolja. Erre a koncepcióra épített Glosten és Milgrom (1985). Modelljük segítségével bemutatták, hogyan nő a spread a kontraszelekció hatására. A specialista a feltételezéseik szerint kockázatsemleges, versengő, valamint a várható profitja nulla. Mindezek mellett végtelen nagyságú készlettel rendelkezik mind pénzből, mind részvényből. A kutatásuk alapján Kornis (2017) az alábbi öt fontos feltételezést vonta le:

- A jegyzett vételi és eladási árfolyam közrefogja azt az árat, amely abban az esetben alakulna ki, ha minden kereskedő pontosan annyi információval rendelkezne, mint a specialista.

- A ténylegesen létrejött tranzakciók árfolyama egy martingál-folyamatot alkot ${ }^{2}$.

- A kontraszelekcióból származó spread korlátos.

- A specialista és az informált kereskedők várakozásai az árfolyamra vonatkozóan konvergálnak.

\footnotetext{
${ }^{2}$ A martingál-folyamatokról részletesebben lásd: Doob (1971)
} 
- Általánosságban nő az eladási és csökken a vételi árfolyam akkor, ha a bennfentes információ javul, ha az informált kereskedők aránya a nem informáltakéhoz képest megnő, vagy ha megnő a likviditási kereskedők várható keresleti és kínálati rugalmassága.

Az eddig tárgyalt irodalmakban a hangsúly végig a bid-ask spread nagyságán volt. A spread azonban, ahogyan azt Harris (1990a) megjegyezte, a piaci likviditásnak csak az egyik dimenziója. Harris (1990a) így definiálta a likviditást: „A piac likvid, amennyiben a kereskedők akkor tudnak alacsony tranzakciós költségek mellett, nagy mennyiségben vásárolni és eladni részvényeket, amikor csak akarnak. A likviditás valamely kereskedő hajlandósága arra, hogy alacsony költség ellenében átálljon a kereskedés másik oldalára, melyet valaki más kezdeményezett." Vagyis a bid-ask spreaden felül a forgalom is egyik mérőszáma lehet a likviditásnak. A likviditási mérőszámokat teljeskörǔen von Wyss (2004) foglalta össze.

A NYSE-n (New York Stock Exchange) a specialista teljes ajánlata tartalmazza mind a vásárlás, mind az értékesítés számára elérhető legjobb árajánlatot, ahogyan a legjobb áron az elérhető részvények számát is, más néven a mélységet (depth). Ha a specialista úgy véli, megnő annak a valószínűsége, hogy az egyes kereskedők bennfentes információval rendelkeznek, akkor arra a bid-ask spread növelésével válaszolhat. Alternatív megoldásként azzal is védheti magát, hogy alacsonyabb volument nyújt kereskedésre minden jegyzett árnál (Lee et al. 1993).

Kyle (1985) definiálta először a likviditást a feszesség, mélység és szélesség (statikus dimenziók), valamint a piaci rugalmasság (dinamikus dimenzió) fogalmak használatával. Az azonnaliság (szintén dinamikus) dimenziója Harris (1990b) nevéhez köthető, a diverzitást pedig már Kutas és Végh (2005) értelmezte külön, új dimenzióként. Így annak okán, hogy a piaci likviditás többdimenziós, meglepő, hogy a szakirodalom nagy része mégis csak a spreadre fókuszál. Számos kontraszelekció mellett vizsgált árjegyzési modell azzal a feltétellel hagyja figyelmen kívül a mélységet, hogy megköveteli, hogy minden kereskedés (és ezáltal a jegyzések is) ugyanazon volumen mellett történjen. Erre láthatunk példát Copeland és Galai (1983), Glosten és Milgrom (1985) és Easly és O'Hara (1992) modelljében. Azok a modellek, melyek megengedik a különböző volumenű kereskedést, mint Kyle (1985) és Rock (1989), tipikusan azt feltételezik, hogy a specialista teljes árjegyzést végez. Ezen modellekben az árral és volumennel kapcsolatos információk egyaránt szükségesek az árjegyzés likviditásának implicit értékeléséhez.

Lee és társai (1993) megmutatták, hogy a specialista aktívan kezelheti az információs aszimmetria kockázatát mind a spread, mind a mélység módosításával. Eredményük kiemeli a mennyiségi dimenzió fontosságát, amit a korábbi modellek elhanyagoltak, s hangsúlyozza azt a tényt, hogy a spread és a mélység együttesen okoz egyértelmű változást a likviditásban. Vagyis a spread szélesedése (szűkülése) a mélység csök- 
kenésével (növekedésével) kombinálva elegendö, hogy csökkenést (növekedést) váltson ki a likviditásban.

Kavajecz (1999) tanulmányában szintén a kontraszelekciós problémából származó kockázat csökkentésével foglalkozott, méghozzá a jegyzett volumen irányából. Az alábbi négy fontos következtetés vonható le az eredményeiből:

- Ha a jegyzés módosul, akkor az esetek kilencven százalékában a specialista megváltoztatja a jegyzett mennyiséget (is), sőt, az esetek ötven százalékában csak a volumen tekintetében változik meg a jegyzés, az árfolyam egyáltalán nem mozdul el. Ebből adódóan a specialista aktívan kezeli saját készletét akkor is, amikor az ár nem változik.

- Ha a piacon túlnyomó többségben vannak a jól informált kereskedők, akkor a specialista jegyzése nagy eséllyel az ajánlati könyv tetejét tükrözi saját készlete helyett. Így biztosítja, hogy egy beérkező piaci áras ajánlat nem saját készletének terhére fog teljesülni, hanem a könyvben lévő legjobb limitáras ajánlatokkal párosul.

- A jegyzett volumenek konzisztensek a specialista saját részvényállományának nagyságával, tehát stratégiájában a mennyiség meghatározása is szerepet játszik.

- Amennyiben új információ kerül nyilvánosságra, akkor mind a specialista, mind a kereskedők csökkentik ajánlataik volumenét.

E gondolat mentén továbbhaladva a Dupont (2000) cikkében a stilizált elméleti keret azt mutatja, hogy a monopolista helyzetben lévő, kockázatsemleges specialista arányosan jobban szúkíti a jegyzés mélységét, mint ahogyan a spreadet szélesíti, amikor a kontraszelekció növekedésére reagál, vagyis az egyensúlyi mélység arányosan érzékenyebben reagál a kontraszelekció változására, mint a spread. A mélység és a spread helyettesítési rugalmassága - tekintettel a bennfentes kereskedő rendelkezésére álló információk minőségére - a piaci kondícióktól függ, melyeket az információs aszimmetria, az eszköz volatilitása és a likviditás iránti kereslet erőssége határoz meg. Ez az elaszticitás a végtelenhez közelít, ha a piaci kondíciók vagy rendkívül kedvezőkké (a mélység a végtelenig bővül, miközben a spread pozitív marad), vagy rendkívül kedvezőtlenekké válnak (a mélység a nullát közelíti, miközben a spread véges marad). Az, hogy az informált kereskedő kockázatsemleges vagy kockázatelutasító, nem befolyásolja alapvetően az eredményeket.

Kavajecz és Odders-White (2001) szerzőpáros azt elemezte, hogy a specialista hogyan frissíti az árjegyzést egy szimultán egyenlet modellben. Arra az eredményre jutottak, hogy az ajánlati könyv legjobb áraiban és volumeneiben végbemenő változások szignifikáns hatást gyakorolnak az árjegyzésre, míg a tranzakciók és más tevékenységek csak másodlagosak. Ezenfelül rámutattak arra, hogy a specialista másképpen vizsgálja felül a jegyzett árakat és a jegyzett volumeneket. Például a jegy- 
zett volumenek bármilyen méretű tranzakció hatására változnak, míg a jegyzett árfolyamok csak akkor, ha a tranzakciók mérete meghaladja a mélységet. Arra nem találtak bizonyítékot, hogy a specialista készletét érintő változások hatására is változik-e az árjegyzés.

Caglio és Kavajecz (2006) tett először kísérletet annak megvizsgálására, hogy a likviditás mennyiségi dimenziójának, azaz a mélységnek a szabályozása okoz-e specifikációs hibát a spread dekompozíciós modelljében. Amit meg kell érteni, az az, hogy csupán a bid-ask spreadben végbemenő változások elegendők-e önmagukban a kontraszelekció nagyságának meghatározására. Más szavakkal: a mélység módosulásának mértéke redundáns információ-e a dekompozíciós eljárásokban?

A szerzők egy egyszerű szekvenciális kereskedési modellt állítottak fel, mely egyedi, analitikus megoldást kínál a specialista optimalizációs problémájára, vagyis arra, hogy hogyan válassza meg az árakat és a volumeneket profitja maximalizálására. A modell a spread kontraszelekciós komponensében bekövetkező változásokat méri, melyek az informált kereskedés különböző szintjei során keletkeznek. Megmutatták, hogy a specialista a jegyzett volument stratégiailag tudja használni a kereskedelmi környezet változásának, illetve a kontraszelekció kockázatának kezelésére. Az eredmény konzisztens a ténnyel, miszerint ha a jegyzés módosul, akkor - hozzávetőlegesen az esetek ötven százalékában - a specialista megváltoztatja a jegyzett mennyiséget, de az árat nem, ahogyan ezt már láttuk korábban is (Kavajecz 1999). Ezt az elméleti keretet használva, két szcenáriót vizsgálva szimulálták a modellt. Az egyikben a specialista nincs korlátozva az árjegyzés szempontjából, a másikban viszont a jegyzett volumenek korlátozottak a maximális likviditási kereskedelemmel. Szimulált sorozatot alkalmazva, a két esetre három dekompozíciós modell becslését hasonlították össze. Úgy találták, hogy a spread komponensekre bontása nem képes megragadni a kontraszelekciós kockázat teljes mértékét, amikor a specialista korlátok nélkül határozhatja meg a mélységet. A megoldás az, hogy a kutatóknak olyan kontraszelekciós intézkedéseket kell alkalmazniuk, melyek e probléma enyhítésének céljából figyelembe veszik a mélységet is és a spreadet is.

\section{A modell}

A modell alapjául Caglio és Kavajecz (2006) munkája szolgált, melyet új elemekkel és módszerekkel egészítettünk ki:

1. Caglio és Kavajecz (2006) feltételezésének megfelelően:

a. feltételezzük, hogy az eloszlások, mint például az elemzett eszköz kifizetéseinek eloszlása, normális.

b. megadjuk a paraméterek értékeit (például a mennyiségi adatokat). 
2. Saját, új feltételezéseink a specialista passzív árjegyzése során:

a. a specialistának a bid-ask spread aktuális mérete alapján javítania kell a jegyzésén attól függően, hogy átlépett-e egy előre megadott határt, vagy sem.

3. A modell összekötése Kornis (2017) munkájával, és ez alapján szimuláció készítése.

Az elemzési keret Caglio és Kavajecz (2006) alapján a következő: Tekintsünk egy szekvenciális kereskedési modellt, amelyben a kockázatos eszköz kifizetése egy $\Theta$-val jelölt valószínúségi változó. A szerzők nem határozták meg az eszköz kifizetéseinek eloszlását, úgyhogy azzal a feltételezéssel éltünk, hogy $\Theta$ normális eloszlású, 100as várható értékkel és 5-ös szórással. Az értékpapír végső értéke $\mu$ valószínūséggel $\theta_{1}$, és $1-\mu$ valószínűséggel $\theta_{2}$, ahol $\theta_{1}<\theta_{2}$. A szimulációt $\mu$ öt különböző értékére végeztük el: $0,49^{3} ; 0,4 ; 0,3 ; 0,2$ és $0,1-r e$.

A kereskedők egyenletes eloszlást követnek a $[0,1]$ intervallumon, legyen e kereskedők $\lambda$ része tökéletesen informált az értékpapír kifizetéséről, $1-\lambda$ része pedig ne birtokoljon semmiféle információt a kockázatos eszköz végső értékéről, ahol $0<\lambda<1$. A szimuláció során $\lambda$ értékét $0,2-n e k$ vettük.

A kereskedőkön felül van még egy szereplő a piacon, a kockázatsemleges, profitmaximalizáló specialista, aki a kockázatos eszköz árjegyzését a saját célja elérésére, $s$ emellett a piaci szabályokat figyelembe véve végzi. A feladata egy vételi ár és mennyiség (bid price and size), valamint egy eladási ár és mennyiség (ask price and size) pár kihirdetése. Ezeknél a meghirdetett áraknál rosszabb árakon és mennyiségeken nem történik tranzakció. Ezenkívül a specialistának van saját véleménye $\lambda$-ról, melyet minden kereskedés után megújít, ezt $\lambda_{s}$-sel jelöltük.

\subsection{Egy periódus alakulása}

Caglio és Kavajecz (2006) egy periódust a következőképpen határozott meg. Elsőként a kockázatos eszköz kétféle kifizetési lehetősége megváltozik. Ezután a specialista meghatározza a jegyzett vételi és eladási árakat ( $b$-vel és $a$-val jelölve, ahol egyensúlyban $b<a$ ), s ezekkel egyetemben a megfelelő vételi és eladási volumeneket ( $\beta$-val és $\alpha$-val jelölve). Ennek során figyelembe veszi a különféle kereskedőkkel való kereskedés valószínúségét, valamint az általuk óhajtott mennyiségeket az adott pénzügyi termékből, és természetesen a pénzügyi termék lehetséges kifizetéseit és várható értékét. A piaci szereplők populációjából egy véletlenszerúen választott személy elhatározza, hogy szeretne-e kereskedni vagy nem. Ha a kereskedő az igen mellett dönt, akkor kiválaszt egy mennyiséget, ami kisebb vagy egyenlő, mint a releváns mélység. Miután megtörtént a tranzakció, a specialista frissíti a korábbi véleményét az informált kereskedők arányáról, és felülvizsgálja a jegyzett ajánlatát.

\footnotetext{
${ }^{3} 0,5$ helyett 0,49-et kell használni, hogy a későbbiekben el tudjuk kerülni a 0-val való osztást, mint például a 4. egyenlet esetében.
} 
Az új ajánlat megszabása után következik egy újabb kereskedési kör, és ez a folyamat ismétlődik meghatározott időn keresztül.

Caglio és Kavajecz (2006) feltette, hogy minden kereskedőnek legfeljebb egyszer van lehetősége a kereskedésre. Annak okán, hogy az informált kereskedőnek tökéletes információja van a kockázatos eszköz végső értékéről, a kereslete elméletileg korlátlan, ha a specialista „félreárazta” az eszközt. Ennek a keresletnek a specialista jegyzett mennyiségei szabnak korlátot, tehát a modell kulcsa az, hogy az informált kereskedők a maximális mélységet fogják választani. Ebből kifolyólag a j-edik informált kereskedő az alábbiak szerint fog ajánlatot tenni:

$$
q_{j}^{i}=\left\{\begin{array}{cc}
-\beta, & \text { ha } b>\theta^{*} \\
|\alpha|, & \text { ha } a<\theta^{*}
\end{array}\right.
$$

ahol $\Theta^{*}$ jelöli a kockázatos eszköz valódi értékét, illetve a $q$ a volument jelöli. Figyelembe kell venni, hogy mivel a specialista vásárol (elad) a bid (ask) árakon, ezért a bid mélység pozitív, az ask mélység pedig negatív, vagyis $\beta_{j}>0$ és $\alpha_{j}<0$.

Mivel a nem informált kereskedők motivációját nem az információ vezérli, egy olyan csoportként lehet rájuk gondolni, mint akiknek különféle, exogén módon determinált motivációja és hajlama van a kereskedésre. A k-adik kereskedőt egy $\left(e_{k}, r_{k}\right)$ páros írja le, mely reprezentálja az általa kereskedni óhajtott mennyiséget (endowment), és a rezervációs árát (reservation price). Az $e_{k}$ pozitív (negatív) értékei azt jelentik, hogy a kereskedő eladni (vásárolni) szeretne egy bizonyos mennyiséget a kockázatos eszközből. Ezenfelül az $r_{k}$ magas (alacsony) értéke azt mutatja, hogy a kereskedő magasra (alacsonyra) értékeli az eszközt. Ennélfogva minden egyes nem informált kereskedő a következő stratégia alapján tesz ajánlatot:

$$
q_{k}^{u}=\left\{\begin{array}{cc}
-\min \left[\beta, e_{k}\right], & \text { ha } e_{k}>0 \text { és } b>r_{k} \\
+\min \left[|\alpha|,\left|e_{k}\right|\right], & \text { ha } e_{k}<0 \text { és } a<r_{k} \\
0, & \text { egyébként }
\end{array}\right.
$$

Eszerint egy nem informált kereskedő akkor fog vásárolni (eladni), ha a rezervációs ára magasabb (alacsonyabb), mint a jegyzett eladási (vásárlási) ár, továbbá a kereskedett volumen legfeljebb akkora, mint az eladási (vásárlási) mélység. A követhetőség érdekében a kereskedők által vásárolni/eladni kívánt mennyiségek egyenletes eloszlásúak egy előre rögzített $t_{1}$ és $t_{2}$ pár között, a rezervációs árak pedig szintén egyenletes eloszlást követnek, $\Theta_{1}$ és $\Theta_{2}$ között, tehát:

$$
e_{k} \sim U\left[t_{1}, t_{2}\right] \quad r_{k} \sim U\left[\theta_{1}, \theta_{2}\right]
$$

Mivel nem voltak adottak, a rögzített $t_{1}$ és $t_{2}$ pár intervallumát [-100, 100]-nak vettük, az $r_{k}-k$ pedig a kockázatos eszköz két lehetséges kifizetései közé esnek, melyeket 
a már korábban említett módon, normális eloszlásból generál a modell. Ezenkívül tegyük fel, hogy mind az $e_{k}-k$, mind az $r_{k}-k$ függetlenek egymástól.

A kétféle kereskedői stratégiát együtt véve Caglio és Kavajecz (2006) azt számolta ki, hogy a

$$
\begin{aligned}
E[\pi(b, \beta, a, \alpha)] & =\mu \lambda \beta\left(\theta_{1}-b\right)+(1-\mu) \lambda \alpha\left(\theta_{2}-a\right) \\
& +(1-\lambda)\left(\frac{t_{2}-\beta}{t_{2}-t_{1}}\right)\left(\frac{b-\theta_{1}}{\theta_{2}-\theta_{1}}\right) \beta\left\{\mu\left(\theta_{1}-b\right)+(1-\mu)\left(\theta_{2}-b\right)\right\} \\
& +(1-\lambda)\left(\frac{\beta}{t_{2}-t_{1}}\right)\left(\frac{b-\theta_{1}}{\theta_{2}-\theta_{1}}\right)\left(\frac{1}{2} \beta\right)\left\{\mu\left(\theta_{1}-b\right)+(1-\mu)\left(\theta_{2}-b\right)\right\} \\
& +(1-\lambda)\left(\frac{\alpha-t_{1}}{t_{2}-t_{1}}\right)\left(\frac{\theta_{2}-a}{\theta_{2}-\theta_{1}}\right) \alpha\left\{\left(\theta_{1}-a\right)+(1-\mu)\left(\theta_{2}-a\right)\right\} \\
& +(1-\lambda)\left(\frac{-\alpha}{t_{2}-t_{1}}\right)\left(\frac{\theta_{2}-a}{\theta_{2}-\theta_{1}}\right)\left(\frac{1}{2} \alpha\right)\left\{\mu\left(\theta_{1}-a\right)+(1-\mu)\left(\theta_{2}-a\right)\right\}
\end{aligned}
$$

Az egyenlet jobb oldalának első sora az informált kereskedőkkel lefolytatott tranzakciókból várható veszteséget jelöli, a többi pedig a nem informált kereskedőkkel kötött nyereséges vagy veszteséges üzletek várható értékét. Ez az optimalizálás implicit feltevéseket tesz a specialista által megválasztott változók kapcsolatáról. Ezeket a feltevéseket az alábbi két korlátozásban lehet összefoglalni:

1) A jegyzett mélység kisebb mint a maximális likviditási kereskedés, vagy egyenlő vele:

$$
t_{1} \leq \alpha<0<\beta \leq t_{2}
$$

2) A jegyzett árak a két végső kifizetés közé kell, hogy essenek:

$$
\theta_{1}<b<a<\theta_{2}
$$

\subsection{Az aktív jegyzési módszer}

A modell egyensúlyi értékeit a következőképpen határozta meg Caglio és Kavajecz (2006):

ÁlLíTÁs 1: Ha $\mu$ eleget tesz az alábbi feltételeknek:

$$
\left(\frac{\lambda-\lambda\left(\frac{t_{2}}{t_{1}}\right)}{1-\lambda\left(\frac{t_{2}}{t_{1}}\right)}\right)<\mu<\left(\frac{1-\lambda}{1-\lambda\left(\frac{t_{1}}{t_{2}}\right)}\right)
$$

akkor az egyperiódusos modell egyedi egyensúlya (unique equilibrium): 


$$
\begin{gathered}
b_{u}^{*}=\frac{1}{4}\left(3 E_{\mu}[\theta]+\theta_{1}\right)-\frac{1}{4}(1-\mu)\left(\theta_{2}-\theta_{1}\right) \sqrt{1+\left(\frac{8}{t_{2}}\right)\left(\frac{\lambda}{1-\lambda}\right)\left(\frac{\mu}{1-\mu}\right)\left(t_{2}-t_{1}\right)} \\
\beta_{u}^{*}=\frac{3}{2} t_{2}-\frac{1}{2} t_{2} \sqrt{1+\left(\frac{8}{t_{2}}\right)\left(\frac{\lambda}{1-\lambda}\right)\left(\frac{\mu}{1-\mu}\right)\left(t_{2}-t_{1}\right)} \\
a_{u}^{*}=\frac{1}{4}\left(3 E_{\mu}[\theta]+\theta_{2}\right)+\frac{1}{4} \mu\left(\theta_{2}-\theta_{1}\right) \sqrt{1-\left(\frac{8}{t_{1}}\right)\left(\frac{\lambda}{1-\lambda}\right)\left(\frac{1-\mu}{\mu}\right)\left(t_{2}-t_{1}\right)} \\
\alpha_{u}^{*}=\frac{3}{2} t_{1}-\frac{1}{2} t_{1} \sqrt{1-\left(\frac{8}{t_{1}}\right)\left(\frac{\lambda}{1-\lambda}\right)\left(\frac{1-\mu}{\mu}\right)\left(t_{2}-t_{1}\right)}
\end{gathered}
$$

A $\mu$-re vonatkozó korlátozás ekvivalens azzal, hogy megköveteljük a specialistától, hogy a piac mindkét oldalát tartsa nyitva. A bal oldali egyenlőtlenség biztosítja a piac eladási oldalát, $a_{u}{ }^{*}<\theta_{2}$ és $\alpha_{u}{ }^{*}<0$, a jobb oldali egyenlőtlenség pedig a vételi oldalt, $b_{u}{ }^{*}>\Theta_{1}$ és $\beta_{u}{ }^{*}>0$.

$\mathrm{A}\left(\mu, \lambda, t_{1}, t_{2}\right)$ változókra vonatkozó korlátok értelmezésének két módja van:

1) Az első interpretáció azt jelenti, hogy a korlátozás elegendő bizonytalanságot követel meg a kockázatos eszköz végső kifizetésével kapcsolatban, azaz $\mu$ ne legyen túl közel se nullához, se egyhez, hogy a specialista ne engedhesse meg magának, hogy lemond a piac egyik oldaláról származó várható profitról azzal, hogy lezárja azt az oldalt.

2) A második interpretáció azt állítja, hogy a korlátozás megköveteli, hogy legyen elegendő nem informált kereskedő a kereskedői populációban, hogy a specialista várható pozíciója nyereséges legyen, azaz $\lambda$-nak közel kell lennie nullához.

Abban a speciális esetben, amikor nincsenek informált kereskedők, vagyis $\lambda=0$, a gyökök eltűnnek, és a jegyzés leegyszerűsödik az alábbiakra $(0<\mu<1)$ :

$$
\begin{gathered}
b_{u}^{*}=\frac{1}{2}\left(E_{\mu}[\theta]+\theta_{1}\right) \\
\beta_{u}^{*}=t_{2} \\
a_{u}^{*}=\frac{1}{2}\left(E_{\mu}[\theta]+\theta_{2}\right) \\
\alpha_{u}^{*}=t_{1}
\end{gathered}
$$

Következésképpen az árak csupán középértékek a várható érték és a végső értékek között, a mélységek pedig lehetővé teszik a kereskedők számára, hogy az általuk megkívánt mennyiségekkel kereskedjenek. 


\subsection{A passzív jegyzési módszer}

Ha $\mu$ nem tesz eleget az (1)-es állításnak, azaz nincs elegendő bizonytalanság a pénzügyi termék kifizetéséről, és/vagy a specialista úgy véli, hogy túl sok az informált kereskedő, akkor Caglio és Kavajecz (2006) egyensúlyi módszere nem múködik. Így azt figyelembe véve, hogy ha a specialista szerint a piacon viszonylag nagy létszámban vannak a jól informált kereskedők, akkor a jegyzése nagy eséllyel az ajánlati könyv tetejét tükrözi (Kavajecz 1999), a jegyzés alakulását a következőképpen kezeltük: Ilyen esetben a specialista tart attól, hogy nagy valószínűséggel egy olyan kereskedő jön, akivel szemben csak veszíthet. Ebből arra lehet következtetni, hogy megpróbál a piaccal együtt mozogni, nem hirdet meg a legjobb áraktól nagymértékben eltérő ajánlatokat.

A feltételezéseink a modellezés során a következők:

1) Ha a bid-ask spread nem nagyobb, mint a megszabott maximális spread (ez egy állítható paraméter a vizsgálat során), akkor a specialista a jegyzéskor az ajánlati könyvben szereplő legjobb vételi ár és mennyiség, valamint legjobb eladási ár és mennyiség párokat hirdeti meg újra.

2) Ha a bid-ask spread nagyobb, mint a megszabott maximális spread, akkor köteles javítani a jegyzésen. Ilyenkor mindkét oldalon eggyel jobb áron hirdet meg egyegy 150 volumenű ajánlatot, ami bekerül az ajánlati könyvbe, de csak az a része marad a könyvben, amely az adott időpontban érkező kereskedővel lefolytatott tranzakció során nem párosult.

\subsection{A $\lambda$-ról való vélemény megújítása}

Ebben a szekvenciális modellben a specialista a $\lambda$-ra vonatkozó várakozásait minden kereskedési kör végén megújítja, és kihirdet egy új árjegyzést a következő körre. Ahhoz, hogy a specialista tanulási folyamata érthető legyen, fontos észrevenni, hogy amikor egy beérkező ajánlat kisebb a meghirdetett eladási vagy vételi mélységnél ( $\alpha$ vagy $\beta$ ), a specialista tudja, hogy az ajánlatot beküldő befektető nem informált, hiszen hogyha egy likviditáskereskedőről van szó, akkor biztos kevesebbet akar venni, mint a mélység, mert nem tudja, merre kéne mozdítani az árat, ugyanis nincs információja afelől, hogy mennyi kellene legyen az árfolyam. Ezzel szemben, amikor a beérkező ajánlat $\alpha$ vagy $\beta$, a specialista nem tudja, hogy az ajánlatot nyújtó személy egy nagy likviditáskereskedő, vagy pedig egy informált kereskedő. Az informált kereskedő elviheti a teljes mennyiséget, mert ő tudja, hogy elmozdíthatja a helyes ár felé az árfolyamot. Azonban az, ha valaki pont elviszi a mélységet, még nem garantálja, hogy nem informált.

Így a specialista a mélységgel egyenlő ajánlatokat Caglio és Kavajecz (2006) szerint a Bayes-szabály alapján értelmezi. Azt feltételezték, hogy az informált kereskedők aránya binomiális eloszlást követ a kereskedői populációban, egy $\lambda$ paraméterrel 
a $[0,1]$ intervallumon. Ráadásul a specialistának van előzetes véleménye $\lambda$-ról, erről azt feltételezték, hogy egyenletes eloszlású. Ekkor, ha a specialista egy $\alpha$ vagy $\beta$ nagyságú ajánlatot figyel meg, akkor $\lambda$ utólagos valószínűsége a következő:

$$
\begin{gathered}
P(\lambda \mid \alpha)=\frac{(1-\mu)(\lambda)}{(1-\mu)(\lambda)+\left(\frac{\alpha-t_{1}}{t_{2}-t_{1}}\right)\left(\frac{\theta_{2}-a}{\theta_{2}-\theta_{1}}\right)(1-\lambda)} \\
P(\lambda \mid \beta)=\frac{(\mu)(\lambda)}{(\mu)(\lambda)+\left(\frac{t_{2}-\beta}{t_{2}-t_{1}}\right)\left(\frac{b-\theta_{1}}{\theta_{2}-\theta_{1}}\right)(1-\lambda)}
\end{gathered}
$$

Minden egyes kereskedés információt hordoz, jelzés a populáció összetételéről. Ezeknek a jeleknek az összesítése definiálja a specialista véleményét az informált kereskedők megoszlásáról a piacon. Ahogy egyre több kereskedési periódus megy végbe, a specialista véleménye arról, hogy éppen milyen valószínúséggel van egy informált kereskedővel dolga, Caglio és Kavajecz (2006) szerint exponenciálisan kell konvergáljon $\lambda$ valódi értékéhez.

ÁLLíTÁs 2. Ha egy kereskedő érkezése a piacra egy binomiális valószínüségi változó egy ismeretlen $\lambda$ paraméterrel, és $\lambda$ elözetes eloszlása egyenletes a $[0,1]$ intervallumon, akkor $N$-böl k db teljes mélységü kereskedés mellett $\lambda$ utólagos várható értéke:

$$
E(\lambda \mid k \text { teljes kereskedés } N \text { kereskedésböl })=\frac{k+1}{N+2}
$$

\section{A szimuláció}

A modellt megtestesítő program Excel VBA-ban készült, a vizsgálatot Monte Carlo-szimulációval végeztük. A program sok összetevőből áll. Egyrészt különféle függvényekből, melyek a bemenő paraméterek változásának hatására rögtön reagálnak és megváltoztatják a függvények értékét, másrészt számos szubrutinból, melyek csak újbóli futtatási parancsra végzik el a számításokat. Ezeknél fontos szerepet játszik a meghívás sorrendje. A program nagyon rugalmas, mert a paraméterek könnyedén állíthatók, így egy-két gombnyomással nagyon sokféle esetet lehet szimulálni.

\subsection{A jegyzés}

A szimuláció egyik kulcseleme a „Specialist” nevü függvény ${ }^{4}$, mely a 3.2. és 3.3. fejezetben tárgyalt kétféle jegyzési módszert kapcsolja össze. Ennek a kimenő értékei a jegyzett vételi ár és mennyiség, valamint az eladási ár és mennyiség (1. táblázat). Ha $\mu$ kielégíti az (1)-es állítást, akkor a Caglio és Kavajecz (2006)-féle egyensúlyi értékek alapján történik a jegyzés az „aktív” módszerrel, ha viszont $\mu$ nem elégíti ki a feltételeket, akkor az adott időpontban a spread értékétől függően a „passzív” módszerrel történik. Ez a kétféle jegyzési stílus a specialista véleménye módosu-

\footnotetext{
${ }^{4}$ Lásd az 1. függeléket.
} 
lásának hatására váltakozik folyamatosan a szimuláció során, mivel a feltételben szereplő $\lambda_{s}$, illetve a különböző esetekhez tartozó $\mu$ értékek jelentik az egyetlen változó paramétert.

\section{1. táblázat}

A specialista jegyzése

Specialista jegyzése

\begin{tabular}{c|c|c|c}
\hline \multicolumn{2}{c|}{ Vétel } & \multicolumn{2}{c}{ Eladás } \\
\hline Volumen & Ár & Volumen & Ár \\
\hline 12 & 99 & -7 & 100 \\
\hline
\end{tabular}

\subsection{Az ajánlatok kezelése}

A másik leglényegesebb komponens az „Ajánlat” nevű szubrutin ${ }^{5}$, melynek n-szeri futtatására épül az egész program. A szimuláció egyik alapvető feltételezése, hogy a specialista jegyzései adják a limitáras ajánlatokat, melyek bekerülnek a könyvbe, a kereskedők ajánlatai pedig a piaci megbízások, melyek a limitáras ajánlatokkal párosulva folyamatosan kiütik azokat a könyvből.

Fontos azonban megérteni a könyvbe kerülés folyamatát. Ha a specialista az aktív módszerrel végzi a jegyzést, akkor a jegyzett ajánlatok bekerülnek a könyvbe. Ha a passzívat kell alkalmaznia, csak akkor kerülnek be, ha javít a jegyzésen, vagyis a spread magasabb volt, mint az általunk megadott paraméter által megengedett. Ellenkező esetben csak a könyv legjobb ajánlatait hirdeti meg újból, tehát ez esetben az ajánlatok nem kerülnek be újra, mivel ekkor egy duplázódó láncreakció indulna be, és az ajánlatok volumenei elszállnának a végtelenbe.

Az átláthatóság érdekében külön vételi és eladási árak helyett egy közös ár oszlopot használtunk, mely 79-től 121-ig tartalmaz értékeket. A kezdőkönyv generálása során az eladási árak várható értéke 105 , szórásuk 7 , a vételi árak várható értéke 95, szórásuk 5, maguknak az ajánlatoknak a volumenei pedig 50 várható értékú, 15 szórású normális eloszlásból vannak véve. (Egy részlet látható a kezdeti ajánlati könyvből a 2. táblázatban).

\footnotetext{
${ }^{5}$ Lásd a 2. függeléket.
} 


\begin{tabular}{|c|c|c|}
\hline $\begin{array}{l}\text { 2. táblázat } \\
\text { Összevont ajánla }\end{array}$ & & \\
\hline & lati $k$ & \\
\hline Vétel & Ár & Eladás \\
\hline & 105 & 63 \\
\hline & 104 & 55 \\
\hline & 103 & 58 \\
\hline & 102 & 174 \\
\hline 72 & 101 & \\
\hline 91 & 100 & \\
\hline 78 & 99 & \\
\hline 123 & 98 & \\
\hline
\end{tabular}

\subsection{A naplók}

A megfigyelések rögzítésére kétféle naplót használtunk. Az egyik az ajánlatok naplója ${ }^{6}$, melybe az ehhez tartozó szubrutin a beérkező új, 0-tól különböző ajánlatokat másolja át, tehát ez a napló összegyűjti az összes olyan esetet, amikor a beérkező kereskedő elfogadta a specialista jegyzését. A napló tartalmazza az ajánlatok volumenét, amiknek az előjele jelzésértékkel bír, az árakat, a vételi vagy eladási irányt, valamint azt, hogy a program az adott kereskedőt informáltnak vagy nem informáltnak generálta. Az utolsó oszlopban már egy másik szubrutin dolgozik, ami a specialista véleményét írja ki, hogy szerinte az a kereskedő informált volt-e, vagy sem (3. táblázat).

\section{3. táblázat}

\section{Ajánlatok naplója}

\begin{tabular}{c|c|c|c|c|c}
\multicolumn{7}{c}{ Ajánlatok naplója } \\
\hline Sorszám & Volumen & Ár & Irány & Trader & Spec vél \\
\hline 1 & -84 & 98 & Eladás & Uninf & \\
\hline 2 & -48 & 96 & Eladás & Uninf & 1 \\
\hline 3 & -51 & 98 & Eladás & Inf & 1 \\
\hline 4 & 7 & 100 & Vétel & Uninf & 1 \\
\hline
\end{tabular}

Érthető módon a specialista nem mindig találja el jól ezeknek a típusát (ez látható a 3. táblázatban), hiszen ő csak azt látja, hogy az adott személy teljes mélységgel kereskedett-e, vagy sem. Ha igen, akkor informáltnak titulálja (ezt jelzi az 1-es

\footnotetext{
${ }^{6}$ Lásd a 4. függeléket.
} 
szám), pedig az is lehet, hogy egy nem informált kereskedő volt, akinek a kereslete véletlenül pont akkora volumenű volt, mint a jegyzett mélység. Ebben a „Spec vél” oszlopban található számok összege adja a (2)-es állításban található $k$ értékét, azaz a teljes mélységű kereskedések számát, egy adott pillanatban a napló utolsó sorszáma pedig $N$ értékét, ami az összes addigi kereskedés számát jelöli.

A másik napló a tranzakciók naplója7, melynek az első öt oszlopát egy, az „Ajánlat” szubrutinba beépített másik szubrutin tölt fel. Az ezután következő négy oszlopot a 4. táblázatban látható módon számítja az Excel.

A tranzakciók naplója az eredmények kivizsgálásának szempontjából használatos.

1. A jutalék oszlopban egész egyszerǔen az ajánlat értéke (volumen·ár) van megszorozva 1,5 százalékkal, ami egy állítható paraméter, a vagyont pedig az aktuális pénzmennyiség és árfolyam szorzata adja.

2. A pénz és a részvények kiszámításánál figyelembe kell venni a tranzakció irányát. Ha eladási megbízás történt, akkor a t-edik tranzakció után a pénz a következőképpen alakul:

$$
\text { pénz } z_{t}=\text { pénz } z_{t-1}+a ́ r_{t} \cdot \text { volumen }_{t}+\text { jutalé }_{t}
$$

Vételi megbízás esetén pedig:

$$
\text { pén } z_{t}=\text { pénz } z_{t-1}-a r_{t} \cdot \text { volumen }_{t}+\text { jutalé }_{t}
$$

3. A részvényeknél pont fordítva, ha eladási megbízás történt, akkor a t-edik tranzakció után csökken a részvényállomány:

$$
\text { részvény }{ }_{t}=\text { részvény }{ }_{t-1}-\text { volumen }_{t}
$$

Vételi megbízás esetén pedig nő:

$$
\text { részvény }{ }_{t}=\text { részvény }{ }_{t-1}+\text { volumen }_{t}
$$

4. táblázat
Tranzakciók naplója
\begin{tabular}{c|c|c|c|c|c|c|c|c|} 
Sorszám & Típus & Volumen & Ár & Spread & Jutalék & Pénz & Részvény & Vagyon \\
\hline 1. & Vétel & 84 & 98 & 3 & 123,5 & 501699 & 993 & 599013 \\
\hline 2. & Vétel & 48 & 96 & 4 & 69,1 & 497161 & 1041 & 597097 \\
\hline 3. & Vétel & 51 & 98 & 4 & 75,0 & 492238 & 1092 & 599254 \\
\hline 4. & Eladás & 7 & 100 & 2 & 10,5 & 492948 & 1085 & 601448 \\
\hline
\end{tabular}

\footnotetext{
${ }^{7}$ Lásd az 5. függeléket.
} 


\section{Az eredmények kiértékelése}

\section{1. Áttekintő statisztikák}

Elsőként egy, a szimuláció egészét kiértékelő statisztikai táblázatot mutatunk be, mely $\mu$ egyes értékeire tartalmaz átlagos eredményeket. Ezeket az 4.3. fejezetben említett tranzakciók naplójának felhasználásával számítottuk ki, Monte Carlo-módszerrel.

\section{5. táblázat \\ Statisztikák}

\begin{tabular}{l|c|c|c|c|c}
\hline Átlagok $/ \mu$ & 0,49 & 0,4 & 0,3 & 0,2 & 0,1 \\
\hline Vagyonnövekedés & 1350 & 9067 & 15414 & 43669 & 81741 \\
\hline$\Delta$ Részvényállomány & 27 & 3631 & 6448 & 9741 & 26998 \\
\hline Jutalék & 793 & 7924 & 12473 & 18532 & 43591 \\
\hline Tranzakciók & 10 & 34 & 39 & 45 & 48 \\
\hline Minimum ár & 95 & 94 & 93 & 94 & 95 \\
\hline Maximum ár & 104 & 105 & 104 & 103 & 103 \\
\hline$\lambda_{i}^{\text {s,v }}$ & 0,30 & 0,25 & 0,20 & 0,15 & 0,11 \\
\hline Átértékelődés & 556 & 1144 & 2940 & 25137 & 38150 \\
\hline
\end{tabular}

Minden eset során 20 kört futtattunk le a programból, ahol egy kör 100 periódust, azaz 100 érkező kereskedőt jelent. A szimuláció során egy kör a következőképpen alakul:

1) Törlődik az ajánlatok és a tranzakciók naplóinak a tartalma.

2) Új kezdőkönyvet generál a program.

3) Lefut 100-szor (állítható paraméter) az „Ajánlat” szubrutin. Minden periódusban behoz egy kereskedőt. Az új ajánlat bekerül az ajánlatok naplójába, a tranzakciót pedig a tranzakciók naplójába könyveli a szubrutin, és módosul az ajánlati könyv. A kereskedők közül természetesen nem mindenki mond igent a specialista ajánlatára, hiszen megeshet, hogy a rezervációs áruk alacsonyabb/magasabb, mint a jegyzett eladási/vételi ár. Ilyenkor nem történik tranzakció, a program fut tovább, és érkezik a következő szereplő. Közben a specialista jegyzése és a kockázatos eszköz lehetséges végső kifizetései folyamatosan változnak.

4) A tranzakciók naplója alapján megtörténik az eredmények kiszámítása.

Ha lefutott a 20 kör, akkor a program kiszámolja az egyes körök végén kapott eredményeknek az átlagát, ezt tartalmazza az 5. táblázat. 
A minimum és maximum árak átlaga között nem állapítható meg jelentős eltérés, $\mu$ változása látszólag nem befolyásolta ezeket egyértelműen. Az árfolyamingadozást viszont igen, erre majd az 5.2. fejezetben fogunk kitérni.

Az 5. táblázatban az is látható, hogy a 100 periódusból átlagosan hányszor történt tranzakció, vagyis hány kereskedő fogadta el a specialista jegyzett ajánlatát. A 2. ábrán egy szép növekedési ütem figyelhető meg $\mu$ csökkenésével.

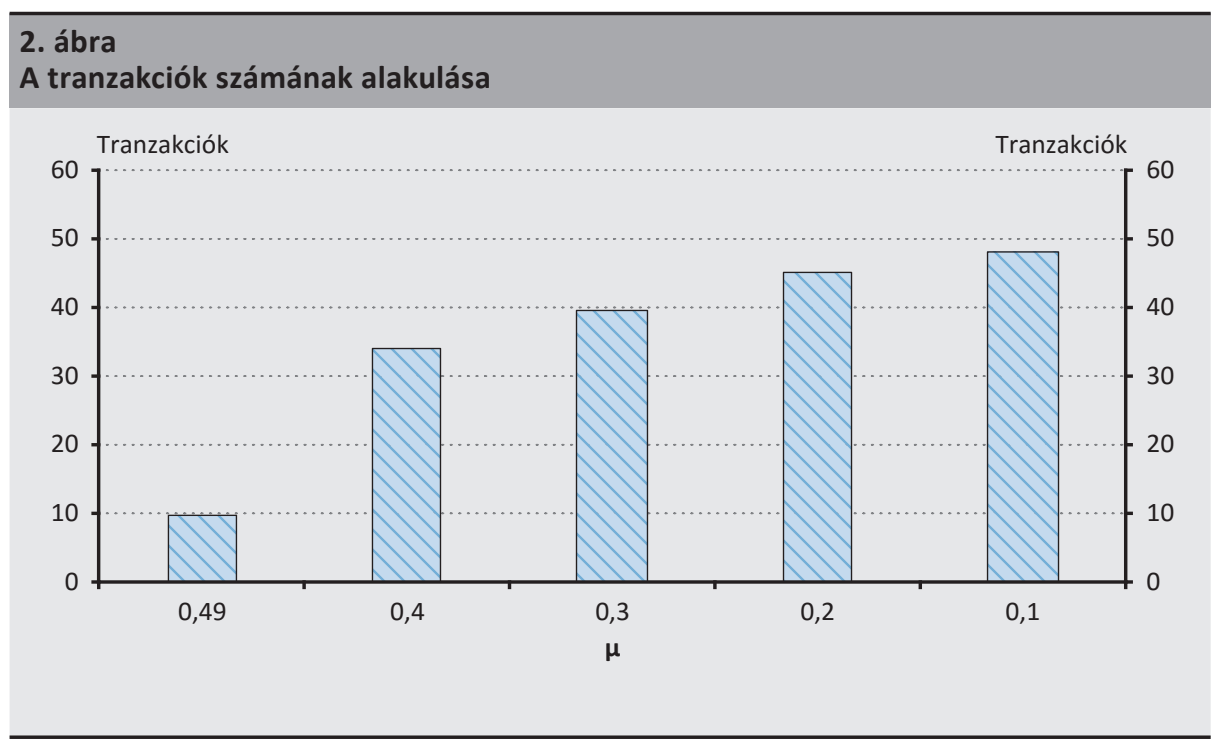

Minél kisebb $\mu$, annál kisebb a bizonytalanság a kockázatos eszköz végső kifizetéséről, s egyúttal egyre kisebb a specialista véleménye is az informált kereskedők arányáról ( $\lambda_{i}^{\mathrm{s}, v}$ a specialista átlagos véleményét jelöli a szimulációs körök végéről), noha $\lambda$ végig $0,2-r e$ volt állítva. Az 5 . táblázatban látni, hogy legjobban $\mu=0,3$ esetén viselkedett a modell, ekkor találta el átlagosan a legpontosabban a specialista $\lambda$ valódi értékét.

Tehát a bizonytalanság csökkenésével nő a tranzakciók száma, ami annak tudható be, hogy a specialista nagyobb valószínúséggel tudja a pénzügyi termék lehetséges árát, ugyanis a megbízások nagyobb valószínűséggel informált kereskedőktől érkeznek, így a piaci ár biztosabban tud konvergálni a tranzakciók során a fair ár felé.

A szimuláció elején a specialista induló vagyona 500000 egység pénz és 1000 db részvény, a jutalék pedig 1,5 százaléknak van beállítva. A tranzakciók nagyobb száma és a nagyobb bizonyosság a termék kifizetéséről együttesen okozhatják, hogy egyre nagyobb a vagyonnövekedés, a részvényállomány és a jutalékok növekedése. Az átértékelődés azt mutatja, hogyan változott a vagyon, ha kivontuk a jutalékok összegét. A 3. ábrán jól látható ez a növekedés. 


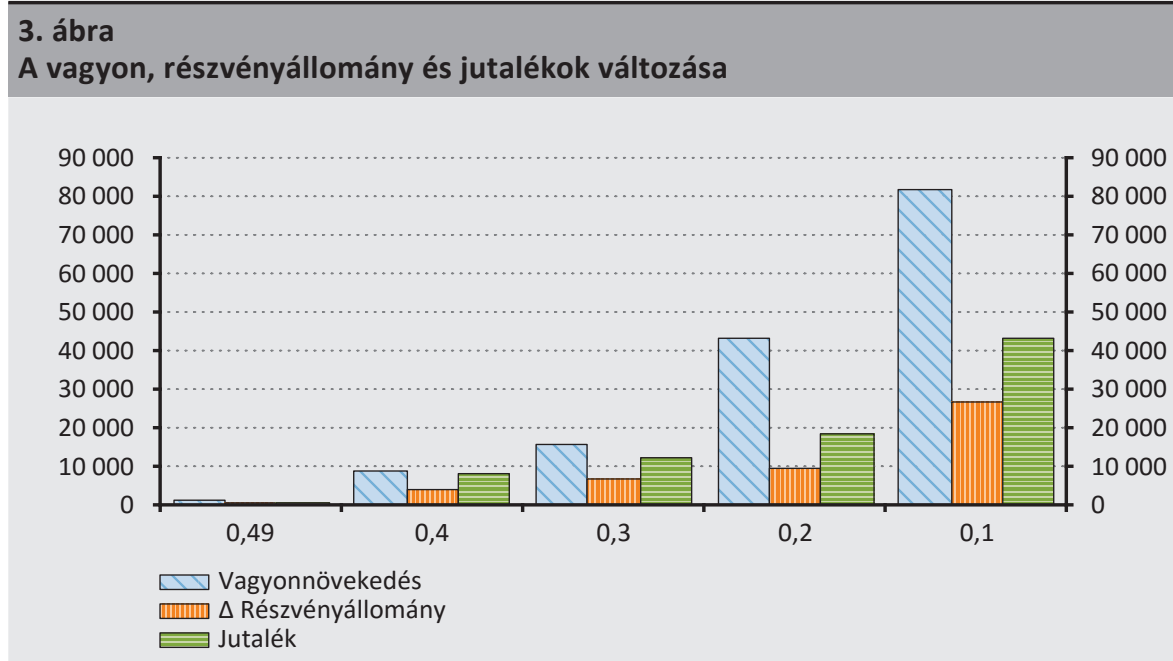

\section{2. Árfolyamok alakulása}

Az árfolyamok alakulásának, s ezeket felhasználva a loghozamok alakulásának vizsgálatához minden $\mu$-re annyiszor futtattuk le a kódot, hogy közel 400 megfigyelést kapjunk mind az öt esetre. Kiszámoltuk ezeknek a maximumát, minimumát, ezek különbségeként a terjedelmet, valamint a szórást.

\section{6. táblázat}

Az árfolyamok minimuma, maximuma, terjedelme és szórása

\begin{tabular}{c|c|c|c|c|c} 
Árfolyam & $\mathbf{0 , 4 9}$ & $\mathbf{0 , 4}$ & $\mathbf{0 , 3}$ & $\mathbf{0 , 2}$ & $\mathbf{0 , 1}$ \\
\hline $\min$ & 81 & 87 & 92 & 91 & 93 \\
\hline $\max$ & 111 & 106 & 113 & 109 & 101 \\
\hline terjedelem & 30 & 19 & 21 & 18 & 8 \\
\hline szórás & 3,95 & 2,85 & 2,09 & 2,20 & 1,86 \\
\hline
\end{tabular}

Bár az 5. táblázat azt mutatja, hogy minden $\mu$ esetén 93-95 között van az átlagos minimum ár, és 103-105 között az átlagos maximum ár az egyes körök végéről, s láthatólag $\mu$ nem gyakorolt egyértelmű hatást az árakra, a 6. táblázatból kiderül, hogy $\mu$ igenis befolyásolta az árak alakulását. Ez a legjobban az egyes esetekhez tartozó szórásokon látszik. Minél kisebb a bizonytalanság, annál kisebb az árak szórása (még nagyobb elemszámmal dolgozva ez még pontosabban mutatkozna meg, s a 0,3-ra kapott eredmény még szebben illeszkedne a 0,4-es és 0,2-es közé), ami konzisztens az 5.1. fejezetben tárgyaltakkal. 
A 4. ábra egyértelmúen azt mutatja, hogy minél kisebb $\mu$, annál kisebb az árak ingadozása.

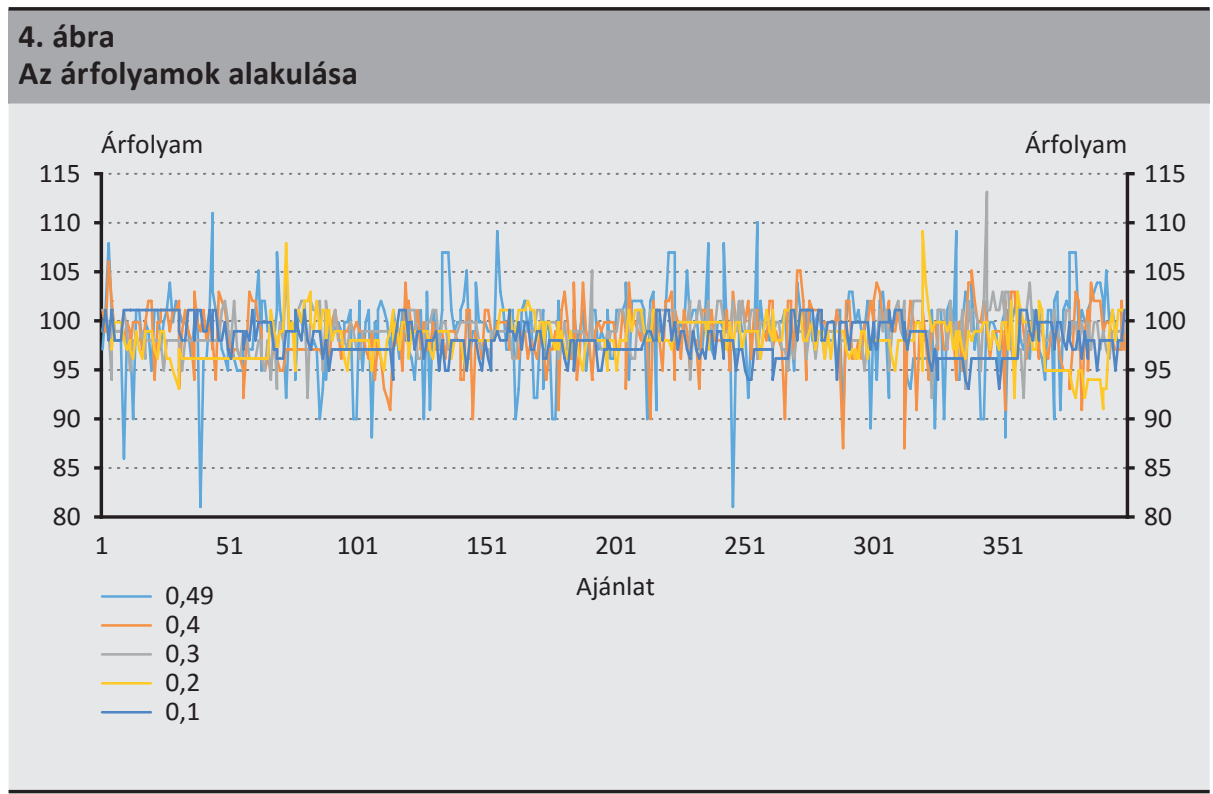

\subsection{A loghozamok alakulása}

A hatékony piacok elmélete (Efficient Market Hypothesis, EMH) azt állítja, hogy a piaci árfolyamok tükrözik a nyilvános információkat, vagyis minden rendelkezésre álló információ beépült az árakba, így az árak megbízhatók (Fama 1970). Ebből kifolyólag az árakat csakis az új információk mozgatják, ami azt eredményezi, hogy a napi loghozamok függetlenek, és normális eloszlást követnek (Száz 2009). Emiatt a fejezet következő részében azt fogjuk vizsgálni, hogy a szimulációval kapott loghozamok eloszlására mennyire igaz ez a következmény.

Az árfolyamokból a láncindexek természetes alapú logaritmusának vételével kaptuk meg a loghozamokat. Ezek minimumát, maximumát, átlagát és szórását a 7. táblázat foglalja össze.

\section{7. táblázat}

A loghozamok minimuma, maximuma, átlaga és szórása

\begin{tabular}{c|c|c|c|c|c} 
Loghozam & $\mathbf{0 , 4 9}$ & $\mathbf{0 , 4}$ & $\mathbf{0 , 3}$ & $\mathbf{0 , 2}$ & $\mathbf{0 , 1}$ \\
\hline $\min$ & $-22,07 \%$ & $-14,92 \%$ & $-11,23 \%$ & $-10,32 \%$ & $-6,19 \%$ \\
\hline $\max$ & $18,03 \%$ & $15,91 \%$ & $10,24 \%$ & $13,75 \%$ & $6,19 \%$ \\
\hline átlag & $0,00 \%$ & $-0,01 \%$ & $-0,01 \%$ & $0,01 \%$ & $0,01 \%$ \\
\hline szórás & $5,38 \%$ & $3,81 \%$ & $2,58 \%$ & $2,14 \%$ & $1,70 \%$ \\
\hline
\end{tabular}


Ezeket a gyakorisági táblázat elkészítéséhez alkalmaztuk, minden esetet külön véve. Elsőként készítettünk a minimum és maximum értékek felhasználásával egy 16 osztályközös abszolút gyakorisági táblázatot. Ebből számítottuk a tényleges relatív gyakoriságokat, majd a tényleges kumulált relatív gyakoriságokat. Ezután egy beépített Excel függvény segítségével kiszámoltuk, hogy milyen értékeket kellene kapnunk egy ilyen átlagú és szórású normális eloszlásból. A kapott számok a normális eloszlás eloszlásfüggvényének az értékei voltak, melyek azonosak az elméleti kumulált relatív gyakorisággal, ebből visszafelé dolgozva megkaptuk az elméleti relatív gyakoriságokat, majd ezek értékeit beszorozva a megfigyelések számával kijöttek az elméleti abszolút gyakoriságok.

A legszebb eredményt $\mu=0,4$-re kaptuk (5. ábra), a loghozamok eloszlása ekkor közelíti a legjobban a normális eloszlást, bár a sűrűségfüggvény még ekkor is jóval csúcsosabb, mint a normális haranggörbe. Az eloszlásfüggvények az elsődleges tengelyhez vannak illesztve, a sürüségfüggvények pedig a másodlagoshoz.

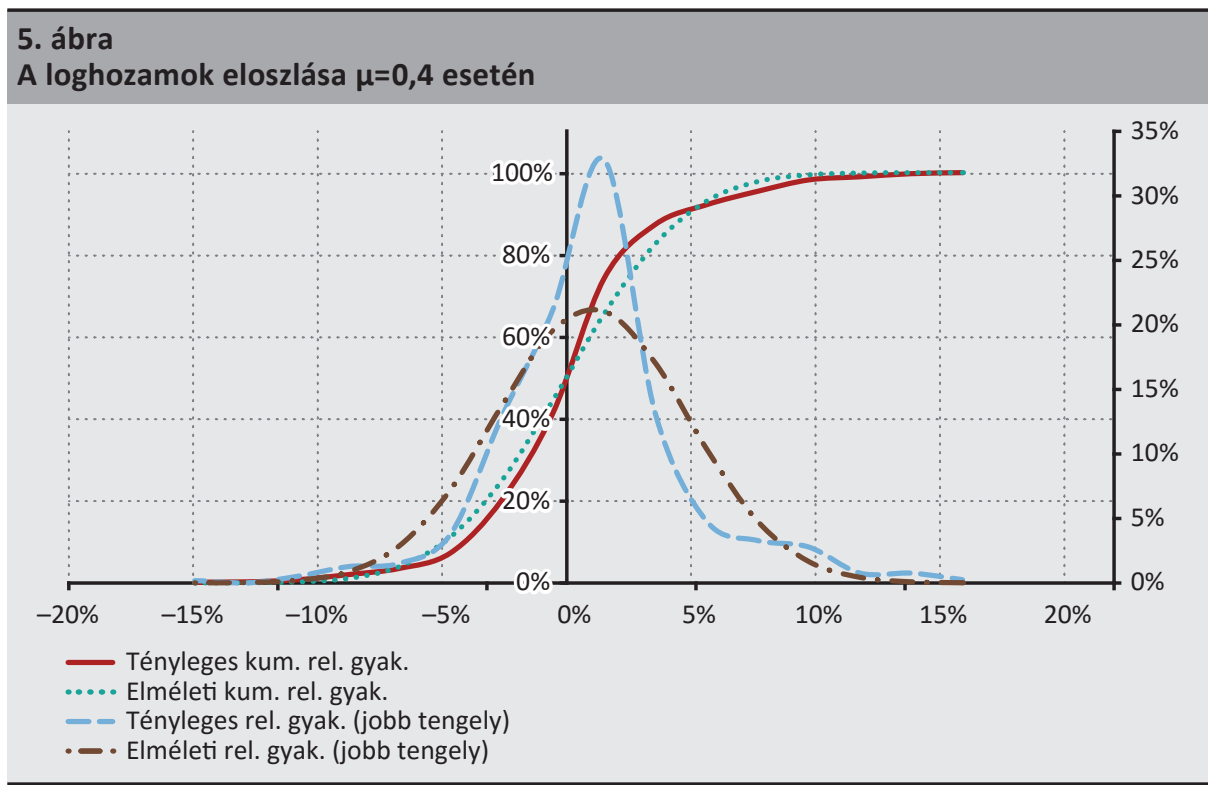

A 6. ábrán együtt ábrázoltuk az ötféle $\mu$ esetén kapott loghozamok eloszlását. A kép kielégíti a várakozásokat, hiszen minél alacsonyabb $\mu$, azaz minél kisebb a bizonytalanság a kockázatos termék végső értékéről, annál jobban torzul a tényleges loghozamok sűrűségfüggvénye a normáliséhoz képest. Tehát minél több információt birtokol a specialista az eszköz kifizetéséről, annál inkább sérül az $\mathrm{EMH}$, miszerint az elérhető információk beépültek az árakba, s így a loghozamok eloszlása valóban egyre kevésbé illeszkedik a normális görbére. Nagyobb elemszámmal dolgozva a folyamatos torzulás valószínúleg még látványosabban rajzolódna ki. 
A $\mu=0,49$-es eset látszólag torzabb a 0,4-esnél, aminek feltehetőleg az lehet az oka, hogy $\mu$ ekkor elég ritkán tesz eleget az (1)-es állításban szereplő egyenlőtlenséggel definiált feltételeknek, és így a passzív jegyzési fajtát alkalmazza a program, nem pedig az aktívat, a Caglio - Kavajecz-féle egyensúlyi modellt.

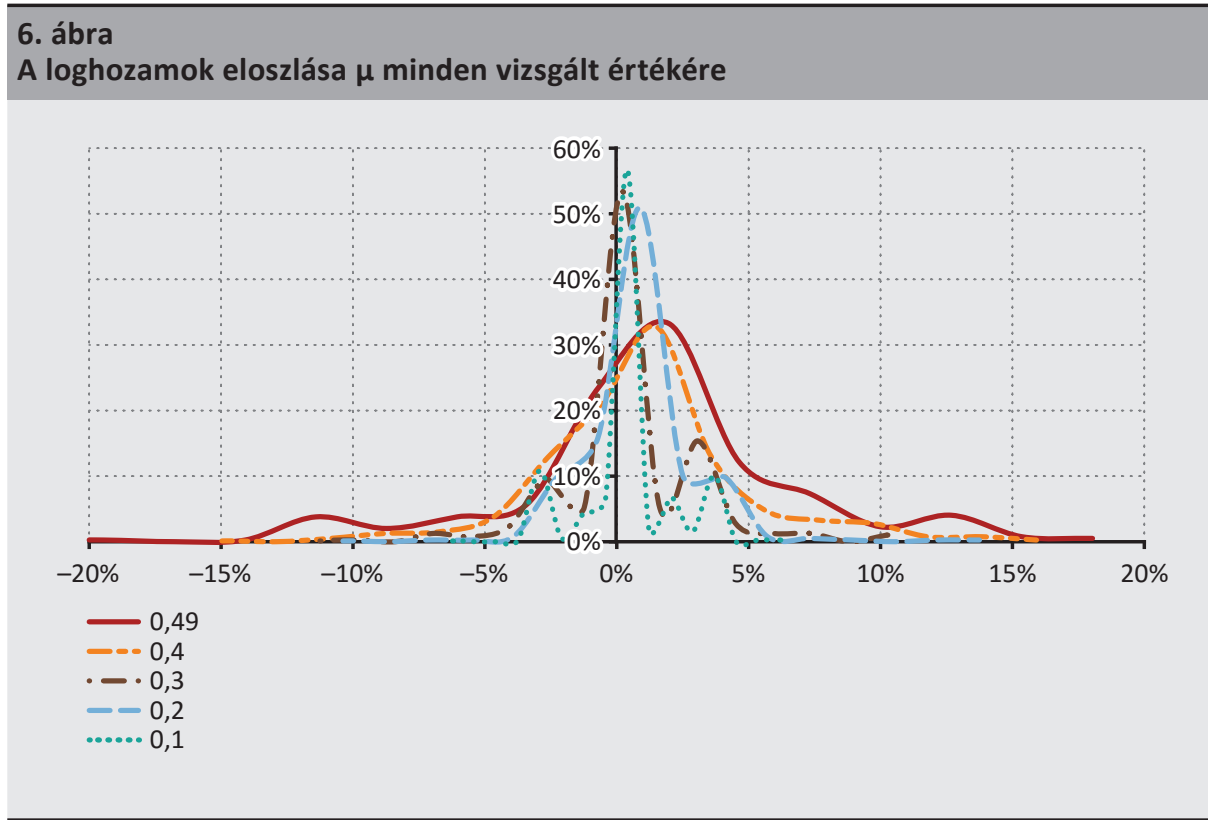

\section{6. Összefoglalás}

Tanulmányunk célja egy olyan szimulációs program megírása volt, melynek segítségével meg tudtuk vizsgálni, hogy a kontraszelekció milyen hatással van a specialista árjegyzésére, a bizonytalanság különböző szintjei hogyan befolyásolják az árfolyamok és a loghozamok alakulását, valamint hogy a specialista a tranzakciók alapján milyen pontosan tudta megállapítani az informált kereskedők arányát a piacon.

A szimuláció során azt kaptuk, hogy a specialista véleménye az informált kereskedők arányáról átlagosan a $\mu=0,3$-as esetben volt a legpontosabb.

Az eredmények egyértelműen azt mutatták, hogy a bizonytalanság csökkenésével egyre nő a tranzakciók mennyisége, mivel a specialista nagyobb valószínűséggel tudja a pénzügyi termék lehetséges árát. Ezzel együtt a specialista vagyona és részvényállománya is folyamatosan növekszik.

Ugyanakkor az árfolyamok ingadozása és a loghozamok szórása egyre csökken, s a hatékony piacok elméletének következménye, miszerint a loghozamok eloszlása 
normális eloszlást követ, egyre jobban torzul, mivel sérül az a feltétel, hogy az árak tükrözik a nyilvános információkat.

A 8. táblázat ezeket az eredményeket foglalja össze. A fordított irányban analóg módon: ha a bizonytalanság nő, akkor az ellenkező irányú változás történik a többi területen.

\section{8. táblázat}

A bizonytalanság változásának hatása

\begin{tabular}{l|c}
\hline Bizonytalanság $(\mu)$ & csökken \\
\hline Tranzakciók száma & nő \\
\hline Vagyon & nő \\
\hline Részvényállomány & nő \\
\hline Árfolyamok ingadozása & csökken \\
\hline Loghozamok szórása & csökken \\
\hline Loghozamok illeszkedése a normális eloszlásra & csökken \\
\hline
\end{tabular}

Az eredmények kielégítették a várakozásainkat, s természetesen nagyobb elemszámra, a program többszöri lefuttatására valószínúleg még pontosabban, tisztábban mutatkoznának meg.

\section{Felhasznált irodalom}

Bagehot, W. (1971): The only game in town. Financial Analyst Journal, 27(2): 12-14. https:// doi.org/10.2469/faj.v27.n2.12

Caglio, C. - Kavajecz, K. A. (2006): A Specialist's quoted depth as a strategic choice variable: An application to spread decomposition models. The Journal of Financial Research, 29(3): 367-382. https://doi.org/10.1111/j.1475-6803.2006.00184.x

Copeland, T. E. - Galai, D. (1983): Information Effects on the Bid-Ask Spread. The Journal of Finance, 38(5): 1457-1469. https://doi.org/10.1111/j.1540-6261.1983.tb03834.x

Demsetz, H. (1968): The cost of transacting. The Quarterly Journal of Economics, 82(1): 33-53. https://doi.org/10.2307/1882244

Doob, J. L. (1971): What is a martingale? The American Mathematical Monthly, 78(5): 451463. https://doi.org/10.2307/2317751

Dupont, D. (2000): Market Making, Prices and Quantity Limits. The Review of Financial Studies, 13(4): 1129-1151. https://doi.org/10.1093/rfs/13.4.1129 
Easley, D. - O'Hara, M. (1992): Time and the Process of Security Price Adjustment. The Journal of Finance, 47(2): 577-605. https://doi.org/10.2307/2329116

Fama, E. F. (1970): Efficient capital markets: A review of theory and empirical work. The Journal of Finance, 25(2): 383-417. https://doi.org/10.2307/2325486

Foucault, T. - Pagano, M. - Röell, A. (2013): Market Liquidity. Oxford University Press, New York.

Glosten, L. R. - Milgrom, P. R. (1985): Bid, ask and transaction prices in a specialist market with heterogeneously informed traders. Journal of Financial Economics, 14(1): 71-100. https://doi.org/10.1016/0304-405X(85)90044-3

Harris, L. (1990a): Statistical Properties of the Roll Serial Covariance Bid/Ask Spread Estimator. Journal of Finance, 45(2): 579-590. https://doi.org/10.1111/j.1540-6261.1990.tb03704.x

Harris, L. (1990b): Liquidity, Trading Rules, and Electronic Trading Systems. New York University Monograph Series in Finance and Economics, Monograph 1990-4.

Kavajecz, K. A. (1999): A Specialist's Quoted Depth and the Limit Order Book. The Journal of Finance, 54(2): 747-771. https://doi.org/10.1111/0022-1082.00124

Kavajecz, K. A. - Odders-White, E. R. (2001): An Examination of Changes in Specialists Posted Price Schedules. The Review of Financial Studies, 14(3): 681-704. https://doi.org/10.1093/ rfs/14.3.681

Kornis Judit (2017): Árjegyzési stratégiák vizsgálata Monte Carlo szimulációval. Szakdolgozat, Budapesti Corvinus Egyetem.

Kutas Gábor - Végh Richárd (2005): A Budapesti Likviditási Mérték bevezetéséről. Közgazdasági Szemle, 52(7-8): 686-711.

Kyle, A. S. (1985): Continuous Auctions and Insider Trading. Econometrica, 53(6): 1315-1335.

Lee, C. M. C. - Mucklow B. - Ready M. J. (1993): Spreads, Depths and the Impact of Earnings Information: An Intraday Analysis. The Review of Financial Studies, 6(2): 345-374. https:// doi.org/10.1093/rfs/6.2.345

O’Hara, M. (1995): Market Microstructure Theory. Basil Blackwell, Cambridge, MA.

Rock, K. (1989): The Specialist's Order Book. Working paper, Harvard University.

Száz János (2009): Pénzügyi termékek áralakulása. Jet Set Tipográfiai Műhely Kft., Budapest.

Von Wyss, R. (2004): Measuring and predicting liquidity in stock market. Universität St. Gallen, PhD-értekezés. 


\section{Függelékek}

Tanulmányunk függelékei az általunk a szimulációhoz megírt legfontosabb szubrutinokat és függvényeket tartalmazzák.

\section{1. függelék: A specialista jegyzésének függvénye I.}

Ahogyan már korábban említettük, a függvény kétféle módszert ötvöz. Ha teljesül a $\mu$-re vonatkozó (1)-es feltétel, ami két egyenlőtlenségből áll, akkor az egyensúlyi értékek a Caglio és Kavajecz (2006) által bizonyítottak alapján alakulnak. Ha az egyenlőtlenség nem teljesül, akkor a program átugrik a következő utasításokra. Ugyanez a parancs fut le akkor is, ha nem csak a második fele, hanem már az első fele se teljesül az egyenlőtlenségnek. A függvény végén a generált vételi és eladási árakat és mennyiségeket egészre kerekíti egy beépített függvény.

Function specialist(mu, v1, v2, lambdaS, t1, t2, spmax, spmost)

Dim Ev, v21, t21

ReDim feltetel(1 To 2)

ReDim bidask(1 To 4)

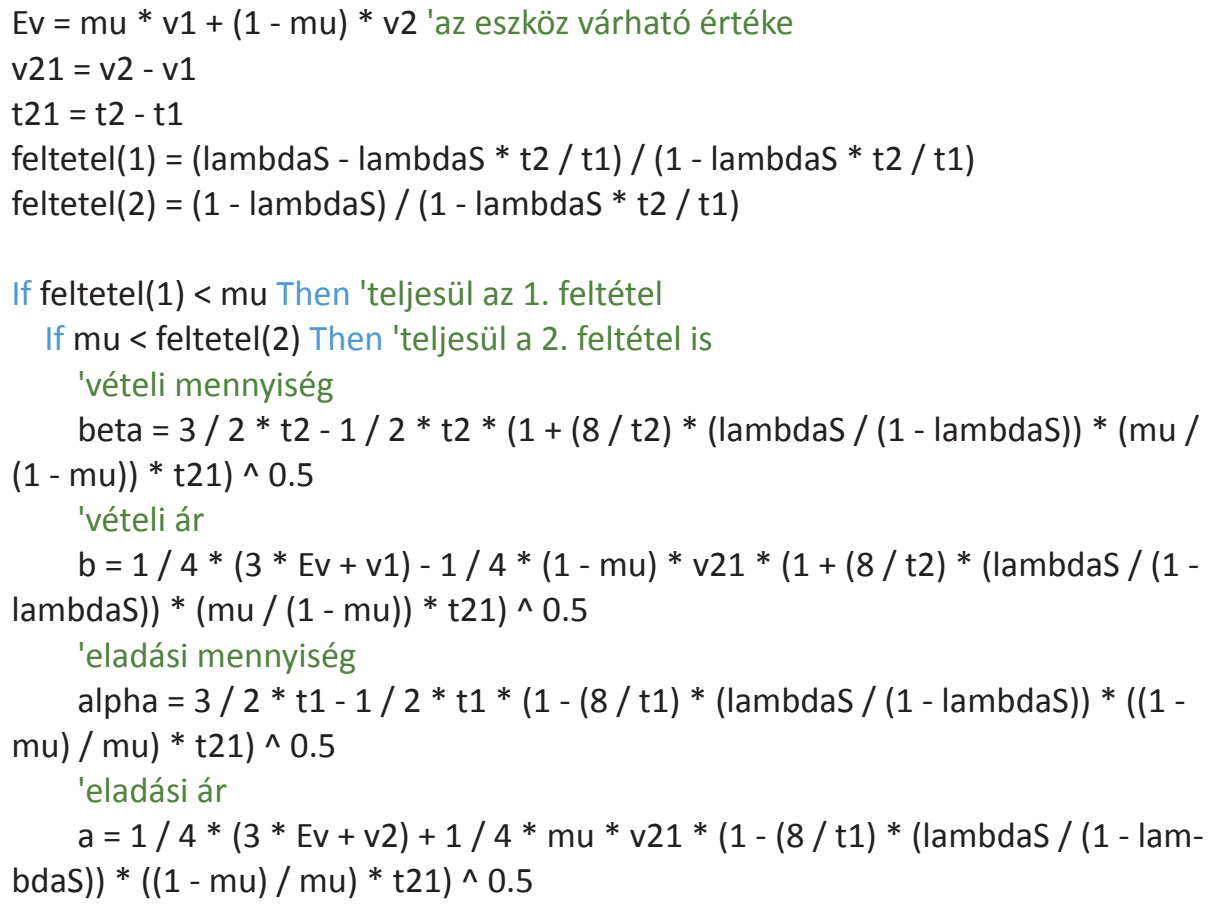

Else 'de nem teljesül a 2. feltétel 


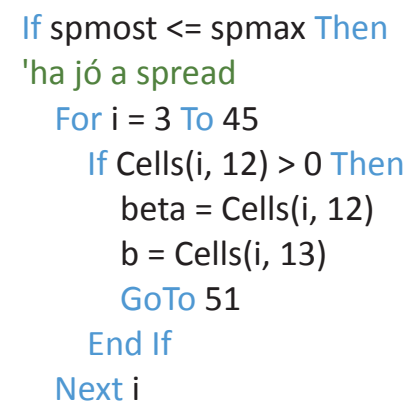

51

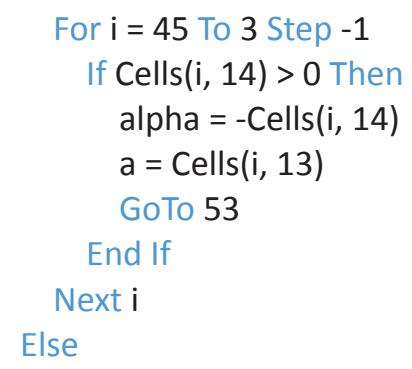

'ha a spread nagyobb, mint a megengedett

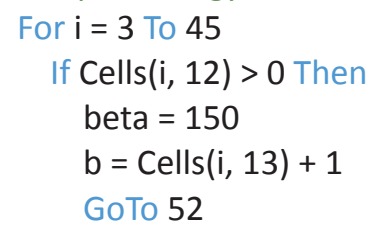

\section{End If}

Next i

52

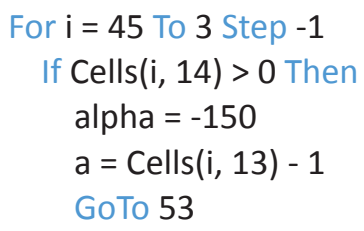

End If

Next i

53

End If

End If

Else 'már az 1. feltétel sem teljesül

If spmost <= spmax Then

'ha jó a spread

For $\mathrm{i}=3$ To 45

If Cells(i, 12) >0 Then 


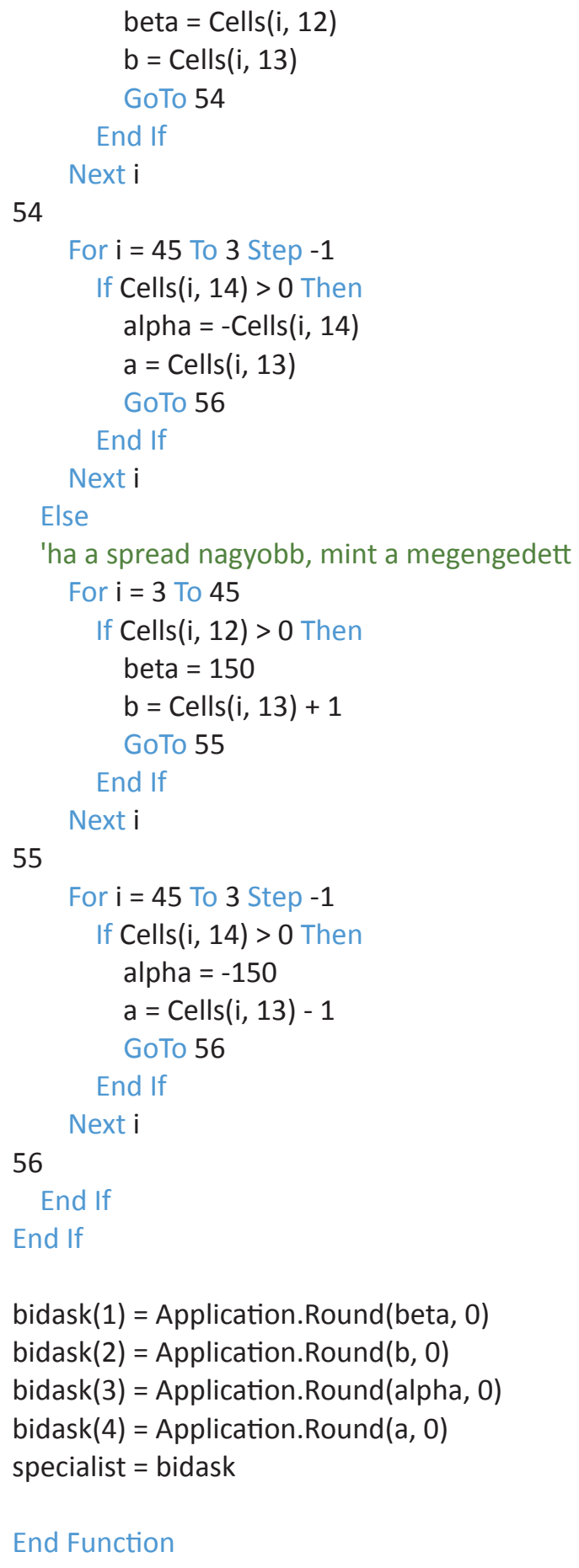

55

For $\mathrm{i}=45$ To 3 Step -1

If Cells $(i, 14)>0$ Then

alpha $=-150$

$\mathrm{a}=$ Cells $(\mathrm{i}, 13)-1$

GoTo 56

End If

Next $\mathrm{i}$

56

End If

End If

$\operatorname{bidask}(1)=$ Application. Round $($ beta, 0$)$

bidask $(2)=$ Application. $\operatorname{Round}(b, 0)$

bidask(3) = Application. Round(alpha, 0)

$\operatorname{bidask}(4)=$ Application. $\operatorname{Round}(\mathrm{a}, 0)$

specialist $=$ bidask

\section{End Function}




\section{2. függelék: Az ajánlat szubrutin}

Ez a szubrutin a legösszetettebb az összes közül. Számos más rutint is meghív, melyek a specialista véleményét frissítik, a kockázatos eszköz értékét változtatják meg, elkönyvelik az ajánlatokat, vagy csak technikai okokból szükségesek.

\subsection{A szubrutin eleje}

Sub ajanlat()

updating_belief 'a specialista véleménye megváltozik a lambdáról az előző ajánlat hatására

kockazatos_eszkoz 'a kockázatos eszköz értéke megváltozik

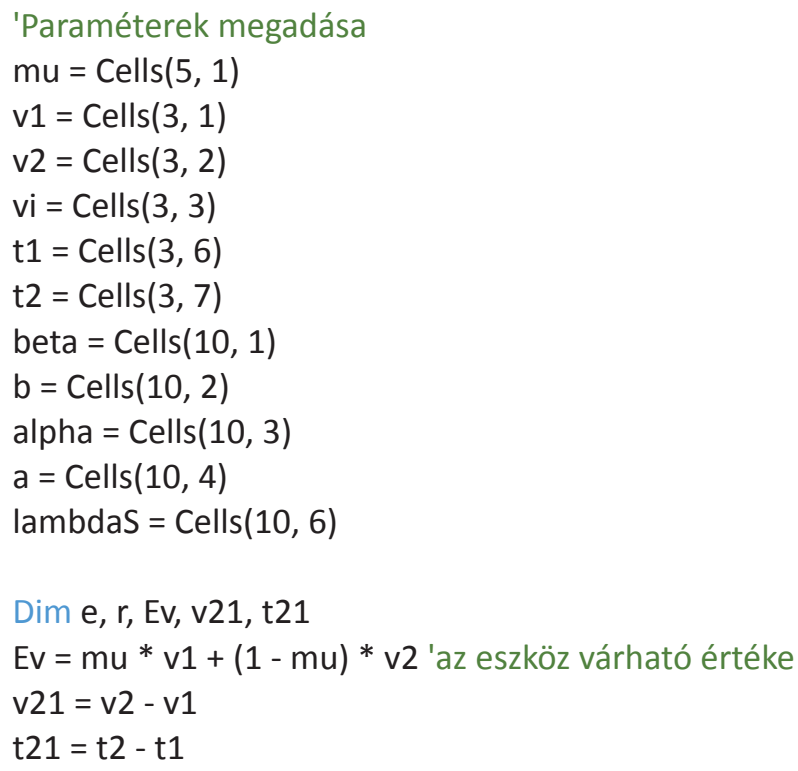

\subsection{A specialista ajánlatainak bekerülése}

\section{'SPECIALISTA:}

'FELTÉTELEZÉS: a specialista ajánlatai a limitáras ajánlatok

ReDim feltetel(1 To 2)

feltetel $(1)=($ lambdaS - lambdaS $*$ t2 $/ \mathrm{t} 1) /(1-$ lambdaS $* \mathrm{t} 2 / \mathrm{t} 1)$

feltetel $(2)=(1-$ lambdaS $) /(1-$ lambdaS $*$ t $2 / \mathrm{t} 1)$

Cells $(4,3)=$ feltetel $(1)$

Cells $(5,3)=$ feltetel $(2)$

$\operatorname{spmax}=\operatorname{Cells}(3,10)$

spmost $=$ Cells $(3,11)$ 
If feltetel $(1)<$ mu Then 'teljesül az 1. feltétel

If mu $<$ feltetel(2) Then 'teljesül a 2. feltétel is

'új jegyzés, ami bekerül a könyvbe

For $\mathrm{i}=3$ To 45

If Cells $(i, 13)=$ Cells $(10,2)$ Then

Cells $(i, 12)=$ Cells $(i, 12)+\operatorname{Cells}(10,1)$ 'specialista vételi volumene

End If

If Cells $(i, 13)=$ Cells $(10,4)$ Then

Cells $(i, 14)=\operatorname{Cells}(i, 14)+\operatorname{Abs}(\operatorname{Cells}(10,3))$ 'specialista eladási volumene End If

Next $\mathbf{i}$

Else

If spmost > spmax Then

'ha a spread nagyobb, mint a megengedett, akkor

'javít a jegyzésen és szintén bekerül az új ajánlat

For $\mathbf{i}=3$ To 45

If Cells $(i, 13)=$ Cells $(10,2)$ Then

Cells $(i, 12)=$ Cells $(i, 12)+$ Cells $(10,1)$ 'specialista vételi vol.

End If

If Cells $(i, 13)=$ Cells $(10,4)$ Then

Cells $(i, 14)=$ Cells $(i, 14)+$ Abs $($ Cells $(10,3))$ 'specialista eladási vol.

End If

Next $\mathbf{i}$

End If

End If

Else

If spmost > spmax Then

'ha a spread nagyobb, mint a megengedett, akkor

'javít a jegyzésen és szintén bekerül az új ajánlat

For $\mathrm{i}=3$ To 45

If Cells $(i, 13)=$ Cells $(10,2)$ Then

Cells $(i, 12)=$ Cells $(i, 12)+\operatorname{Cells}(10,1)$ 'specialista vételi volumene

End If

If Cells $(i, 13)=\operatorname{Cells}(10,4)$ Then

Cells $(i, 14)=$ Cells $(i, 14)+\operatorname{Abs}(\operatorname{Cells}(10,3))$ 'specialista eladási volumene End If

Next i

End If

End If

\subsection{Informált kereskedő generálása}

'KERESKEDŐK: 


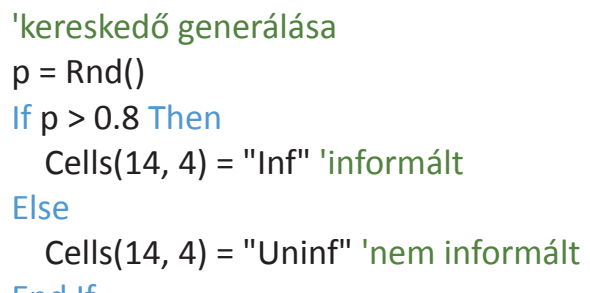

\section{End If}

'informált kereskedő

If Cells $(14,4)=$ "Inf" Then

If $\mathrm{b}>$ vi Then

Cells $(14,1)=-$ beta 'volumen

Cells $(14,2)=$ b 'ár

Else

If $\mathrm{a}<\mathrm{vi}$ Then

$$
\begin{aligned}
& \operatorname{Cells}(14,1)=\text { Abs(alpha) } \\
& \operatorname{Cells}(14,2)=a
\end{aligned}
$$

\section{End If}

\section{End If}

\section{End If}

\subsection{Likviditási kereskedő generálása}

'nem informált kereskedő

If Cells $(14,4)$ = "Uninf" Then

$\mathrm{e}=$ Application.WorksheetFunction. RandBetween(t1, t2)

$r=$ Application.WorksheetFunction.RandBetween(v1, v2)

Cells $(3,8)=\mathrm{e}$

Cells $(3,9)=r$

If e $>0$ Then 'el akar adni

If $\mathrm{b}>\mathrm{r}$ Then 'alacsonyabb a min eladási ára, mint a spec vételi ára

Cells $(14,1)=-$ Application.WorksheetFunction.Min(beta, e)

$$
\text { Cells }(14,2)=b
$$

Else

$$
\text { Cells }(14,1)=0
$$

\section{End If}

\section{End If}

If e $<0$ Then 'venni akar

If $\mathrm{a}<\mathrm{r}$ Then 'magasabb a max vételi ára, mint a spec eladási ára

Cells $(14,1)=$ Application.WorksheetFunction.Min(Abs(alpha), Abs(e))

Cells $(14,2)=a$ 
Else

$\operatorname{Cells}(14,1)=0$

End If

End If

End If

\subsection{Eladási ajánlat}

ajanlatok_naploja 'bevezetjük egy naplóba az ajánlatokat

'az új ajánlat paramétereit elmentjük új változókba

ajanlatvol = Abs(Cells $(14,1))$ 'absérték kell, mert ha eladási ajánlat, akkor negatív a vol.

ajanlatar $=$ Cells $(14,2)$

ajanlattipus $=$ Cells $(14,3)$

'FELTÉTELEZÉS: a kereskedők ajánlatai a piaci áras ajánlatok

If ajanlattipus = "Eladás" Then 'piaci áras eladási

a1 = ajanlatvol

$k=0$

For $\mathrm{i}=3$ To 45

$k=i+1$

If Cells $(i, 13)=$ ajanlatar Then

If Cells(i, 12) >= a1 Then

'ha több van a könyvben, mint amekkora az ajánlat (maradéka)

Cells $(\mathrm{i}, 12)=$ Cells $(\mathrm{i}, 12)$ - a1 'TRANZAKCIÓ

Cells $(14,6)=$ a1 'utolsó tranzakció volumene

Cells $(14,7)=$ Cells $(i, 13)$ 'utolsó tranzakció ára

naplo

$\mathrm{a} 1=0$

Else

'ha kevesebb van a könyvben, akkor tovább osztódik az ajánlat

a1 = a1 - Cells $(\mathrm{i}, 12)$

Cells $(14,6)=$ Cells $(i, 12)$ 'utolsó tranzakció volumene

Cells $(14,7)=$ Cells $(i, 13)$ 'utolsó tranzakció ára

naplo

Cells $(i, 12)=0$ 'TRANZAKCIÓ

GoTo 21

End If

End If

Cells $(6,10)=a 1$

Next i 


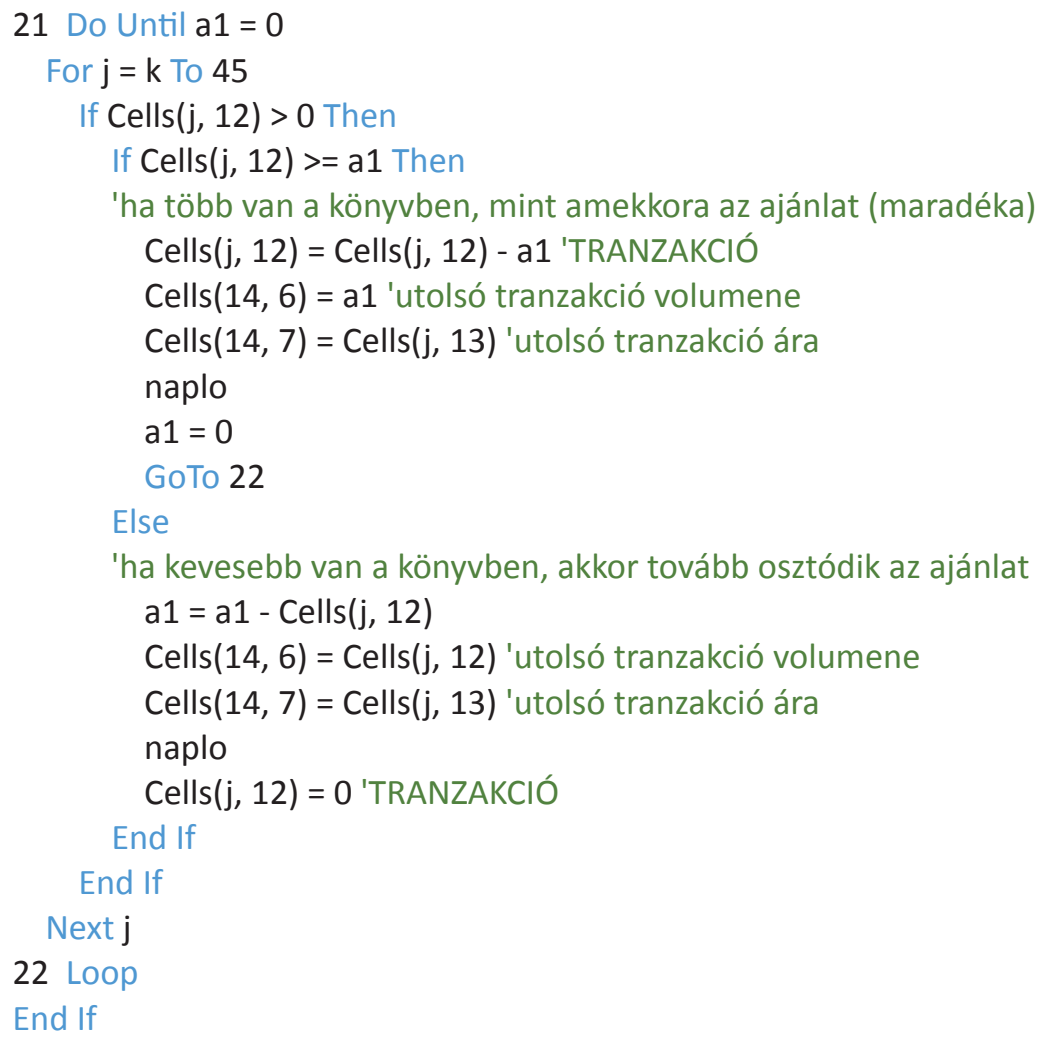

\subsection{Vételi ajánlat}

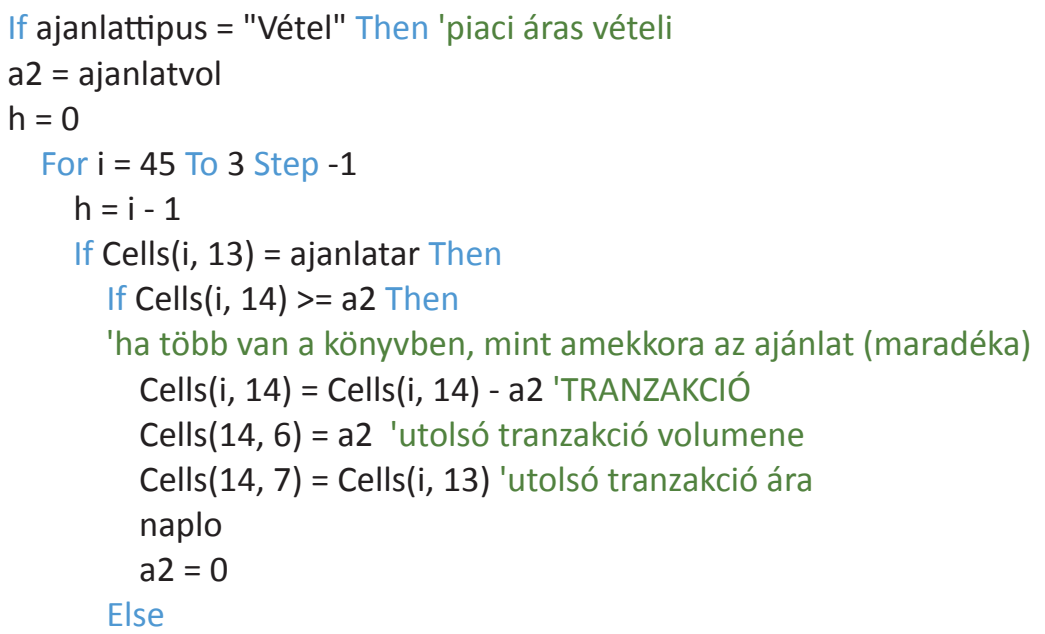

'ha kevesebb van a könyvben, akkor tovább osztódik az ajánlat a2 = a2 - Cells (i, 14) 


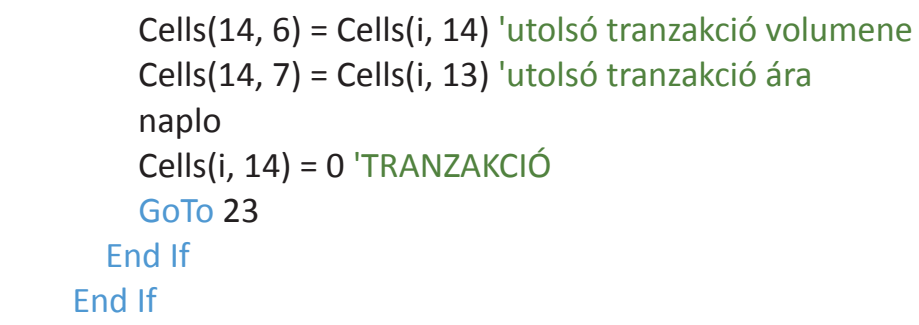

Cells $(6,11)=a 2$

Next i

23 Do Until a2 = 0

For $\mathbf{j}=\mathrm{h}$ To 3 Step -1

If Cells $(j, 14)>0$ Then

If Cells $(j, 14)>=$ a2 Then

'ha több van a könyvben, mint amekkora az ajánlat (maradéka)

Cells $(\mathrm{j}, 14)=$ Cells $(\mathrm{j}, 14)-\mathrm{a} 2$ 'TRANZAKCIÓ

Cells $(14,6)=$ a2 'utolsó tranzakció volumene

Cells $(14,7)=$ Cells $(j, 13)$ 'utolsó tranzakció ára

naplo

$\mathrm{a} 2=0$

GoTo 24

Else

'ha kevesebb van a könyvben, akkor tovább osztódik az ajánlat

$\mathrm{a} 2$ = a2 - Cells $(\mathrm{j}, 14)$

Cells $(14,6)=$ Cells $(j, 14)$ 'utolsó tranzakció volumene

Cells $(14,7)=\operatorname{Cells}(j, 13)$ 'utolsó tranzakció ára

naplo

Cells $(j, 14)=0$ 'TRANZAKCIÓ

End If

End If

Next j

24 Loop

End If

nettositas 'nettósítás az ajánlati könyvben

End Sub 


\section{3. függelék: A specialista véleményének frissítése}

Az "updating belief" szubrutint hívja meg elsőként az "Ajanlat" sub. A $k$ és $N$ értékét az ajánlatok naplójából, majd $\lambda_{\mathrm{s}}$-et, azaz a specialista véleményét az informált kereskedők arányáról a (2)-es állítás képlete alapján számolja.

Sub updating_belief()

$$
\begin{aligned}
& \text { beta }=\text { Cells }(10,1) \\
& \text { alpha }=\operatorname{Cells}(10,3) \\
& k=\operatorname{Cells}(10,7) \\
& i=23 \\
& \text { Do Until Cells }(i, 1)=0 \\
& i=i+1 \\
& \text { Loop } \\
& N=\text { Cells }(i-1,1) \text { 'utolsó sorszám } \\
& j=22+N \\
& \text { If Cells }(j, 2)=\text { alpha * }(-1) \text { Then } \\
& \text { Cells }(j, 6)=1 \\
& \text { End If } \\
& \text { If Cells }(j, 2)=\text { beta * }(-1) \text { Then } \\
& \text { Cells }(j, 6)=1
\end{aligned}
$$

\section{End If}

\section{End If}

$$
\text { lambdaS }=(\mathrm{k}+1) /(\mathrm{N}+2)
$$

Cells $(10,6)=$ lambdaS

Cells $(10,8)=\mathrm{N}$

\section{End Sub}




\section{4. függelék: Az ajánlatok naplója}

Az ajánlatok naplója a 4.3. fejezetben leírtak alapján múködik.

Sub ajanlatok_naploja()

$i=23$

Do Until Cells $(i, 1)=0$

$$
\mathrm{i}=\mathrm{i}+1
$$

Loop

If Cells $(14,1)<>0$ Then

Cells $(\mathrm{i}, 1)=\mathrm{i}-22$

Cells $(i, 2)=\operatorname{Cells}(14,1)$

Cells $(i, 3)=$ Cells $(14,2)$

Cells $(i, 4)=$ Cells $(14,3)$

Cells $(i, 5)=$ Cells $(14,4)$

End If

End Sub

\section{5. függelék: A tranzakciók naplója}

Az tranzakciók naplója a 4.3. fejezetben leírtak alapján működik.

Sub naplo()

$\mathrm{i}=2$

Do Until Cells(i, 17) = 0 'megnézzük, hányadik sorba írhatja a következő tranzakci-

ót

$\mathrm{i}=\mathrm{i}+1$

Loop 'az új i sorba írja a tranzakciót

Cells $(\mathrm{i}, 17)=\mathrm{i}-1$ 'utolsó tranzakció sorszáma

Cells $(i, 19)=$ Cells $(14,6)$ 'volumen

Cells $(i, 20)=$ Cells $(14,7)$ 'ár

Cells $(i, 21)=\operatorname{Abs}($ Cells $(10,4)-$ Cells $(10,2))$ 'spread

'minden tranzakció egyik oldalán a specialista áll

If Cells $(14,3)$ = "Vétel" Then 'ha a bejövő ajánlat vételi volt

Cells $(i, 18)=$ "Eladás" 'a specialista eladott

End If

If Cells $(14,3)$ = "Eladás" Then 'ha a bejövő ajánlat eladási volt

Cells $(i, 18)$ = "Vétel" 'a specialista vásárolt

End If

End Sub 


\section{6. függelék: A kockázatos eszköz értékének változása}

A kockázatos eszköz végső értékének két lehetséges kimenetelét $N \sim(100,5)$ eloszlásból veszi. A kódban v1 megfelel a modellben $\Theta_{1}$-gyel jelölt változónak (egyik lehetséges kimenetel, $\mu$ valószínúséggel), v2 a $\theta_{2}$-ot (másik lehetséges kimenetel, $1-\mu$ valószínűséggel), w pedig $\Theta^{*}$-ot (a valódi végső kifizetés) jelöli.

Sub kockazatos_eszkoz()

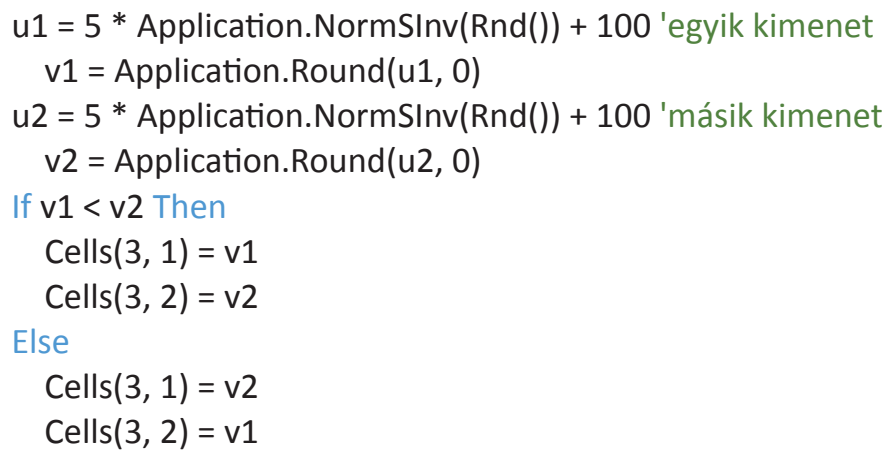

\section{End If}

$$
\begin{gathered}
\mathrm{w}=\operatorname{Rnd}() \\
\mathrm{mu}=\operatorname{Cells}(5,1) \\
\text { If } \mathrm{w}<=\mathrm{mu} \text { Then } \\
\mathrm{vi}=\mathrm{v} 1 \\
\text { Else } \\
\mathrm{vi}=\mathrm{v} 2
\end{gathered}
$$

End If

Cells $(3,3)=$ vi 'valódi érték

\section{End Sub}




\section{7. függelék: Az eredmények kiszámítása}

Az "eredmények" szubrutin a tranzakciók naplójában található adatokkal dolgozik minden kör végén. A körök végi eredmények átlagát tartalmazza az 5. táblázat, amit az 5.1. fejezetben elemeztünk.

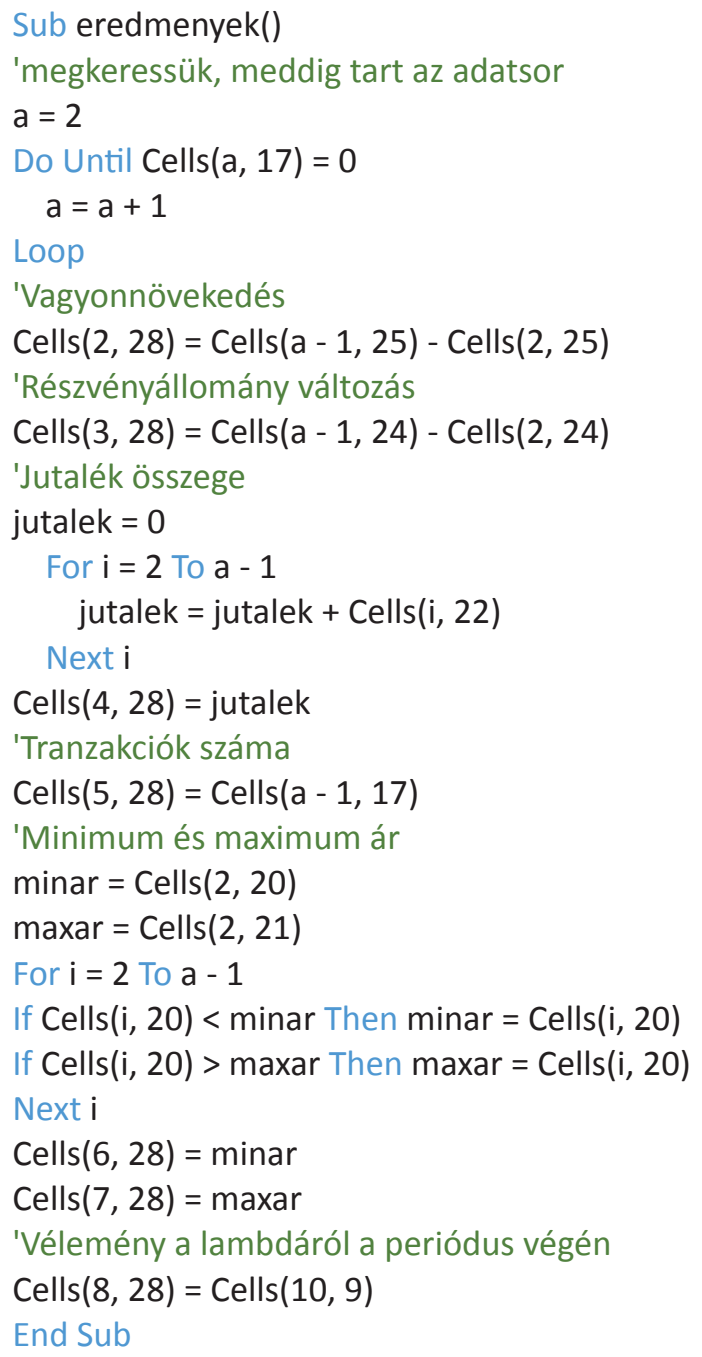

